\title{
STRUCTURE AND DEVELOPMENT OF THE SENSE ORGANS OF THE LATERAL CANAL SYSTEM OF SELACHIANS (MUSTELUS CANIS AND SQUALUS ACANTHIAS) ${ }^{1}$
}

\author{
SYDNEY EVANS JOHNSON \\ Instructor in Anatomy, Northwestern University Medical School \\ EIGHTY-THREE FIGURES
}

CONTENTS

I. Introduction. .................................... 1

II. Brief comments on the literature...................... 3

III. Material, methods and terminology ..................... 9

IV. Observations....................................... 19

A. Mustelus canis . ............................. 19

1. Distribution of the canals and their gross innervation...... 19

2. Structure of the sensory canals.................. 22

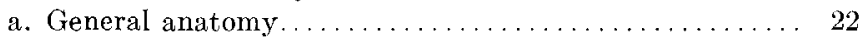

b. Histology of the sensory epithelium............ 23

c. Peripheral terminations of the nervus lateralis....... 26

3. Development of the sensory canals of Mustelus.......... 32

B. Squalus acanthias. ............................. 34

1. Development of the sensory canal system............ 34

a. Early stages of development -9 to $36 \mathrm{~mm} \ldots \ldots \ldots \ldots .34$

b. Later stages of development -40 to $72 \mathrm{~mm} \ldots \ldots \ldots \ldots 58$

2. Structure of the sensory canals of the adult........... 65

V. Summary, conclusions and comparison of the forms studied........ 69

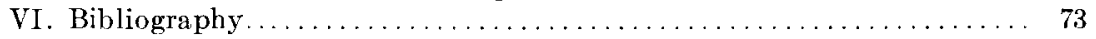

\section{INTRODUCTION}

For nearly 200 years after its discovery in selachians, in 1664, the canal system of fishes was supposed to be mucous secreting, and it was not until 1850 that Leydig produced histological evidence showing that the organs within the canal system of the head of bony fishes are sensory in nature.

${ }^{1}$ Contribution from the Zoological Laboratory of Northwestern University under the direction of William A. Locy. 
F. E. Schulze carried observations a step further and, in 1861, published sketches of histological preparations that embraced bony fishes and gilled amphibia and included in his observations the sense organs of the trunk as well as those of the head. Nevertheless, it was not till the publication of Leydig's elaborate paper of 1868 on organs of a sixth sense that the sensory nature of the canal organs was generally recognized. From that time onward the designations sense organs of the lateral line, or of the lateral canal system, came more and more into use.

Steno's observations, published in 1664 and 1667, were confined to pores of the head of a skate (1664) and of a shark (1667).

Lorenzini, a disciple of Redi, soon thereafter (1678) discovered another set of tubular organs on the head of selachians that had been unknown to Steno. These have long been designated the ampullae of Lorenzini.

Another variety of follicular organs, distributed on the lips and near the mouth of Torpedo, were described and figured in 1844 by Savi.

These three sets of organs have been somewhat confused in discussions of the sense organs of the lateral canal system. Accordingly it is essential to state at the outset that in this paper the ampullae of Lorenzini and the corpuscles of Savi are not taken under consideration.

As regards the sensory nature of these various organs, Jacobson, in 1813, maintained on the basis of reasoning that the ampullae of Lorenzini were sensory organs, probably of a highly elevated sense of touch, and Savi, in the comments on his original sketches of corpuscles of the torpedo, points out they are provided with more nerves than blood vessels and concludes that the also are sensory.

The main question, however, which concerns the canal organs, remained untouched, and it was reserved for Leydig and Schulze to take up the investigation on broader lines. Leydig on the basis of his morphological and histological observations ('50) concluded that the lateral line organs of the head are sensory in nature and not merely mucous secreting and Schulze ('61 and 
70) extended this to organs of the lateral line of the trunk of teleosts and amphibians. No earlier author had reached this conclusion, for the conclusions of Jacobson and of Savi applied only to particular organs of restricted range, while Leydig's and Schulze's were for the first time applied to the widely distributed lateral line organs common to fishes and to amphibians in their aquatic stages.

Since 1870 morphological studies of the lateral line system of fishes have taken two directions: (1) more extensive studies of topography including the anatomical pattern, the nerve supply, the comparative distribution and (2) studies of histology and embryology. It is in the second division named that investigation is most needed. While advances have been made in other directions, little progress has been made in reference to histological detail. The embryonic development is also imperfectly known except in its more general features. The method of growth of the sense organs, the formation of the canals, the position of the neuroblasts, the nature of the peripheral terminations of nerve fibers and the histological structure of the sense organs remain in doubt.

It was with the hope of adding something to this phase of the subject that the investigation reported below was undertaken. The observations cover the period from September, 1914, to June, 1916, and were carried on in the zoological laboratory of Northwestern University under the supervision of Prof. William A. Locy, to whom grateful acknowledgment is accorded for inspiration and pertinent criticism.

\section{BRIEF COMMENTS ON THE LITERATURE}

The literature on the canal system prior to 1850 is of little importance from the morphological point of view. The two papers of Steno ${ }^{2}$ describing the distribution of supposed mucous pores on the head of the skate (1664) and of the shark (1667)

2 Regarding his name, Steno is the form commonly adopted at the present time, but the Latinized, Stenonis, was generally used by its owner rather than the Danish form, Steensen. 
are merely of historical interest. The two rays dissected by Steno were probably Raia batis and the shark, which he designates as Canis carchariae, was identified by J. Mueller as Carcharodon rondeletii, Mueller and Henle. The latter paper was published in Florence in 1667, though the date usually given is that of the Amsterdam edition of 1669 . Since the publication, in 1910 , of the complete scientific works of Steno these papers are readily accessible to readers.

The illustrated memoir of Lorenzini (1678) is diffieult to obtain and I have not had access to it in the original.

Savi's paper of 1844 was read, but it is relatively a side issue so far as organs of the sensory canal system are concerned. $\mathrm{He}$ figures and describes corpuscles that exist under the skin near the mouth and the lips of Torpedo. On account of the obvious size of the nerves of these corpuscles he regarded them as sensory structures.

We may take Leydig's paper of 1850 as the first step in the scientific demonstration that the organs of the canal system are sensory in nature. By histological studies of the knob-like organs in the canals of the head of a fresh water teleost (Kaulbarsch, Acerina cernua) he concludes, from their structure and from their connection with a nerve, that they are sense organs. He mentions those of the lateral line of the trunk but nearly all that he says applies to the knob-like organs of the canals of the head. He thinks at this date that the nerves come from the trigeminus and the vagus and their fibers seem to him to terminate between the long slender cells of the sensory knobs.

Eleven years later, F. E. Schulze ('61), then a medical student working under the direction of Max Schultze at Rostock, gave an analysis of the histological structure of young stages of the perch (Perca fluviatilis) and of larvae of gilled amphibians (Triton). His sketches show the structure of the organs not only of the head region but also of the trunk. He found those of the tail region similar in structure but somewhat simpler than those of the head. His sketches of both perch and Triton show hair-like processes extending from the sensory cells into a hyaline tube and he maintains that the fibers terminate in 
the bases of the 'hairs.' Although subsequent researches with the help of better histological methods have shown that Schulze was wrong in reference to the termination of the nerve fibers, still, we have foreshadowed in this paper the most important question regarding the sense organs - the existence of clubshaped sensory cells with hair-like processes and the relation or nerve fibers to these sensory cells.

Then followed, in 1868, Leydig's paper on organs of a sixth sense, in which he extended his observations to skin organs of amphibians and reptiles. He gives a comprehensive review of the early literature, including his own work of 1850 on the canal organs of teleost fishes, but in this paper he does not give sketches of the structural condition in fishes. The figures are limited to amphibia and certain skin organs of reptiles.

Schulze's paper of 1870 is fully illustrated for young teleosts and amphibia and made more clear and definite that, structurally, the chief characteristic of these sense organs is the presence of pear-shaped hair-cells, and that the nature of nerve terminations is the fundamental point of investigation.

By these researches the ground had been cleared, and the question outlined for neurological investigation was the histological structure of the sense organs and the nature of nerve terminations. But investigations along these lines were retarded for lack of proper histological technique and reliable methods of impregnation of nerve fibers.

All this, also, was before the demonstrations of His upon the origin of nerve fibers ('88) and the formulation of the neuron theory by Waldeyer ('91). Regarding the nerve terminations there arose a period of discussion as to whether there was continuity (Merkel '80) or merely contiguity between nerve fibers and sensory cells.

On account of the close generic resemblance between the sense organs of the lateral line and those of the ear it will not be out of place to mention in this connection two papers on terminations of the eighth nerve. Among others, Ayers ('90) represents the conception of continuity (his diagram, Plate XII) between ganglionje fibers and sensory hair-cells of the internal ear. 
Morrill's demonstration ('98) of the nature of nerve terminations among the hair-cells of the ampullae of the ear is equally distinct on the side of contiguity. This paper with its excellent results has been frequently overlooked even by investigators of the nerve terminations of the eighth nerve.

Neurological investigations led finally to the recognition that we have free nerve terminations among sensory cells and these came to be designated as secondary sense cells. In the sensory epithelium of the lateral canals we have a good illustration of these secondary sense cells.

The literature in reference to topography and gross distrikution of the nerves is extensive and embraces widely known standard contributions as those of Malbranch '76, Amphibians; Ramsay Wright '84, Ameiurus; Garman '88, Selachians; Allis '88, Amia, and others. Following these are the papers of Ewart '93, Lemargus; Ewart and Mitchell '93, Raia; Cole '95, Chjmaera; Collinge '94, Fishes; Clapp '98, Batrachus; Allis '02, Mustelus; Norris '07, Amphibians; Ayers and Worthington ' 07 , Bdellostoma; Reese '10, Chimacra.

In reference to the acustico-lateralis system of nerves contributions have been made by Herrick '99, '01, '05, '06; Johnston '06; Landacre '14, ganglia, etc. A number of authors have particularly cmphasized the relationship between the sensory canal system and the ear.

On the embryological side Balfour's classic observations on elasmobranch fishes ('78) mark the beginning. Other embryological studies include those of Beard '83, metameric condition; Allis '88, connection between ear and nose; Mitrophanow '93, surface views of development from a primordium embracing the epithelium of the ear; Wilson and Mattocks '95, primordia of ear, lateral line and branchial ganglia forming a furrow and sac; Harrison '03, experimental observations of the growth of lateral line organs of amphibia.

The publications that are more closely related to the subject of this paper are those showing histology of the sense organs and their nerve terminations excluding those that relate specifically to the ampullae of Lorenzini and the vesicles of Savi. 
Positive observations in reference to histology and especially those showing nerve terminations are limited in number. But it has been repeatedly shown since Schulze's papers of 1861 and 1870 that pear-shaped and club-shaped sensory cells with cuticular hairs or bristles are characteristic of the sense organs of the canal system. The sensory cells of the sense-hillocks are central in position, do not extend to the basilar membrane and are intermingled and surrounded by long, usually slender, supporting elements extending from the basilar to the limiting membrane. Cells of this kind have been figured with more or less detail by Langerhans '73, Salamandra maculosa, good; Malbranch '76, several amphibians; Solger ' 80 , a nerve plexus in teleosts; Bodenstein '82, Cottus gobio; Mauer '92, fishes and amphibians including Acanthias and Triton; Kingsbury '95, Diemyetylus, Nectorus; Heilig '12, Kaulbarsch, shows nerve terminations; Pfüller '14, Macruridae.

A number of observers from Leydig '50 onwards have published figures of the specific nerve of the sense organs traced to the basilar membrane without showing nerve terminations. Among the early ones are Allis '88, Maurer '92, etc. But the vexed question of the nerve terminations has proved elusive. Retzius '92 supplied good figures of nerve terminations of end bulbs of fishes and amphibians. Bunker '97 makes definite statements without illustrations of the nerve terminations in Amieurus nebulosus. Heilig '12, gives the best figures and the best summary for the Kaulbarsch (Acerina cernua) and Pfüller '14, shows ganglion cells and some fibers in the sense organs of the Macruridae.

The papers of Bunker, Heilig and Pfüller require separate mention.

Bunker '97, by using several methods including haematoxylin stains, Golgi and methylen-blue, worked out the histology of the nerve cells and of the nerve terminations. It is greatly to be regretted that his clear descriptions are not accompanied by sketches. He finds the usual pear-shaped hair-cells in the superficial half of the organ. The nerve at the base of the organ consists of 10 or 20 medullated fibers which lose the medullary 
sheath and break up into a number of branches without anastomoses. These branches pierce the membrane in many places and rise, still branching, to the bases of the sensory cells. Around the bases some of the fibers intertwine in a kind of basket-like network from which fibrillations rise still higher, nearly to the free border of the organ.

Heilig ' 12 by publishing sketches of the histology of the sense organs and the terminations of the nerve fibers took an advanced step. His findings in reference to endings of the nerve fibers are similar to those of Bunker. Heilig's sketches are confined to teleosts and chiefly to the Kaulbarseh (Acerina cernua), which was the form investigated by I Leydig in 1850 . The title of his paper is more comprehensive, embracing the lateral canal organs of fishes and amphibia, and his comments on the literature are broad and comparative. Heilig shows that the nerve fibers lose their medullary sheath just below the sense organ, and piercing the basilar membrane, they spread out tree-like ascending between the supporting cells to the region of the sensory cells. The terminal branches form a sort of cup around the bases of the hair-cells (secondary sense-cells) which brings the cell bodies into close relation. The upward extending fibers do not reach the limiting membrane. One fiber can send its terminal twigs to more than one hair cell. There is no anastomosis between the terminal fibrillae. These points are shown in the sketches but the difficulties of impregnation encountered by all observers and the difficulties of obtaining good pictures of the histology leave room for clearer pictures.

Pfüller '14 published observations on the lateral canal organs and on the nervous system of the head of the Macruridae-a family of deep sea fishes. Only that part of his paper that deals with the lateral line organs is pertinent to the subject under consideration. He shows long slender supporting cells and short thick hair cells, both elements containing rounded nuclei near their bases. The sense-hillocks of the head are richer in sensory cells than those in the lateral canal of the trunk. His histological figures are lacking in details. In his 
figures of Macrurus fastiatus and M. cavernosus are shown small ganglion cells at the base of the sense organ and also within the region of the epithelium. So far as I have been able to determine nothing of this kind exists in Mustelus and Squalus. The relatively small size of his 'ganglion cells' is in marked contrast with the large nerve fibers of the nervus lateralis and of the far removed ganglion cells of the selachians.

\section{MATERIAL, METHODS AND TERMINOLOGY}

The material available for this investigation consisted of a large number of Squalus acanthias embryos ranging from the open neural groove stage to small adults (garters), and Mustelus canis adults and pups, and a few rather poorly preserved embryos of this species between $26 \mathrm{~mm}$. and $80 \mathrm{~mm}$. in length. Squalus embryos between $36 \mathrm{~mm}$. and $72 \mathrm{~mm}$. were not plentiful and there were none between $72 \mathrm{~mm}$. and $180 \mathrm{~mm}$. The Squalus material had been fixed in the usual reagents and preserved in alcoholic and formalin solutions. Fresh Mustelus adults and pups were secured at the Marine Biological Laboratory, Woods Hole, Massachusetts.

Only a few words need be said concerning the methods employed. With preserved material iron haematoxylin gave the best results for sections. No success attended my efforts to secure silver impregnation of the peripheral nerve terminations of preserved specimens. The binocular dissecting microscope was found to be indispensable in dissecting and studying the distribution and nerve supply of the sensory thickenings in early embryos.

With fresh Mustelus material, good impregnations of the peripheral nerve terminations were obtained. Several modifications of the Ramón y Cajal method gave fairly good results, but the best preparations were obtained by a slight modification of the silver-pyridine method introduced by S. W. Ranson.

The modification I found most successful may be outlined as follows: Fresh specimens are decapitated, and narrow strips of integument containing the sensory canals desired are rapidly removed, cut into short sections, rinsed briefly in distilled water, drained on blotting paper, and put into a large volume of ab- 
solute aleohol to which has bcen added 1 per cent of strong ammonia. At the end of four hours the ammonia fixative is poured off and replaced with fresh fluid. In this the tissue should remain from two to four days. The tissue is then rinsed in distilled water and put into a 7 per cent solution of nitric acid for twelve hours. ${ }^{3}$

\section{ABBBREVIATIONS}

Ac.O., accessory organ

Aud., auditory vesicle

$A$ ud.Gn., auditory ganglion

Br.O., branchial sense organs of l3eard

B.Cl., basal cell

Buc.VHI., Ramus buecalis VII

Can., canal wall

Clm., columnar supporting cell

Der., dermis

Dt.Fn., ductus endolymphaticus or its pore

Dor.L., dorsal line of pit organs or their anlagen

Dor.O., dorsal line organ

Ect., ectoderm

Ep.Po., epidermal pocket or tunnel

$E p d$, epidermis

$E p . F_{l}$., epidermal fold

$F$ r., terminal fibrillae

$F b . Z n .$, longitudinal fiber zone

Grp., one group of 'hair-cells'

$H$., hair-like process of sccondary sense ccll

$H y m_{\text {., hyomandibular canal }}$

I.Orb., infraorbital canal

I.Orb.Cd., infraorbital sensory cord

Lat. $N v$., nervus lateralis

Lat.Cn., lateral canal or its pores

Lat. Gn., lateral ganglion

Medl., spinal medulla

Mn.Ex.VII, ramus mandibularis externus VII
Mnd., mandibular canal

Mrd.I'l.O., mandibular line of pit organs

$M . N f$, medullated nerve fiber

$M$ us., musele

$N . M . F b .$, non-medullated nerve fibers

Po., pore of tubule

Pt.O., isolated pit organs or their anlagen

R.Dor., ranus dorsalis of lateral nerve

R. Supt., ramus supratemporais of lateral nerve

$R m l .$, ramulus lateralis

Ri., root of lateral nerve

Sin.Cl., secondary sense cell

Sn.Col., sensory column

S.Orb., supraorbital canal

s.Orb.C:d., supraorbital sensory cord

Spr.., spindle-shaped supporting cell

Sp.Gn., spinal ganglion

Sup.Oph.VII, ramus ophthalmicus superficialis VII

Supt., supratemporal commissure

Tub., tubule

Var., varicosity

$V a s .$, vascular space or blood cell

$V$., fifth nerve, root, or ganglion

$V I I$, seventh nerve, root, or ganglia

$I X$, glossopharyngeal, root, or ganglion

$X$. , vagus, roots; or ganglia

${ }^{3}$ After the manuseript for this paper had gone to The Wistar Institute, my attention was drawn to the fact that a practically identical modification of the pyridine silver method was employed in 1913 by G. C. Huber and S. R. Guild, and is described in the authors' paper on the peripheral distribution of the nervous terminalis in mammalia. The Anatomical Record, volume 7, page 253. 
This treatment was found to be of great advantage as it facilitates sectioning the tough dog-fish integument and also prevents deposits of silver in the connective tissue elements, a drawback which was encountered in the use of other silver reduction methods.

The pieces of tissue are again rinsed in distilled water and then dehydrated in 80 per cent, 95 per cent, and absolute ammoniacal alcohol. From the absolute alcohol the pieces are put directly into pyridine. In this they remain for twenty-four hours, and are then washed for the same length of time in running water. The tissues are then washed for half an hour in distilled water and put into 2 per cent silver nitrate solution, at $37^{\circ} \mathrm{C}$., for two to seven days. When the pieces of tissue in this solution have acquired the proper color they are rinsed briefly in distilled water, reduced in a 2 per cent solution of hydrochinon in 4 per cent formol, dehydrated rapidly, cleared in benzol, and imbedded in paraffin.

After treatment with the nitric acid solution it was often found advantageous to remove the sensory canal from its 'dermal tunnel.' This could be done quite readily with the aid of a pair of sharp needles and a dissecting microscope.

The greatest disadvantage of the method as outlined above is due to shrinkage of tissue and the failure to show cell boundaries in the sensory epithelium. The cell boundaries, however,

Fig. 4 Diagram illustrating the general relations of the lateral nerve and its ramuli to the lateral sensory canal with its surface tubules. Drawn from camera sketches except that the distance between serial ramuli and tubuli has been greatly foreshortened.

Fig. 5 Longitudinal section of the lateral canal of a Mustelus 'pup' at the level of the first dorsal fin. 'This semidiagrammatic figure is a composite, several preparations having been utilized in its construction. The nerve fibers and fibrillae were drawn from pyridine silver and the cellular parts from haematoxylin preparations. The sketch shows the nerve distribution and the general histological structure of the sensory epithelium. $\times 240$.

Fig. 6 Transverse section of lateral canal at the site of a surface tubule. The tubule passes through the dermis in a ventro-lateral direction, opening on the surface near the base of the slightly modified scale. Mustelus canis pup. $\times 85$.

Fig. 7 From the same specimen as the above, more highly mannified. $\times 260$. 


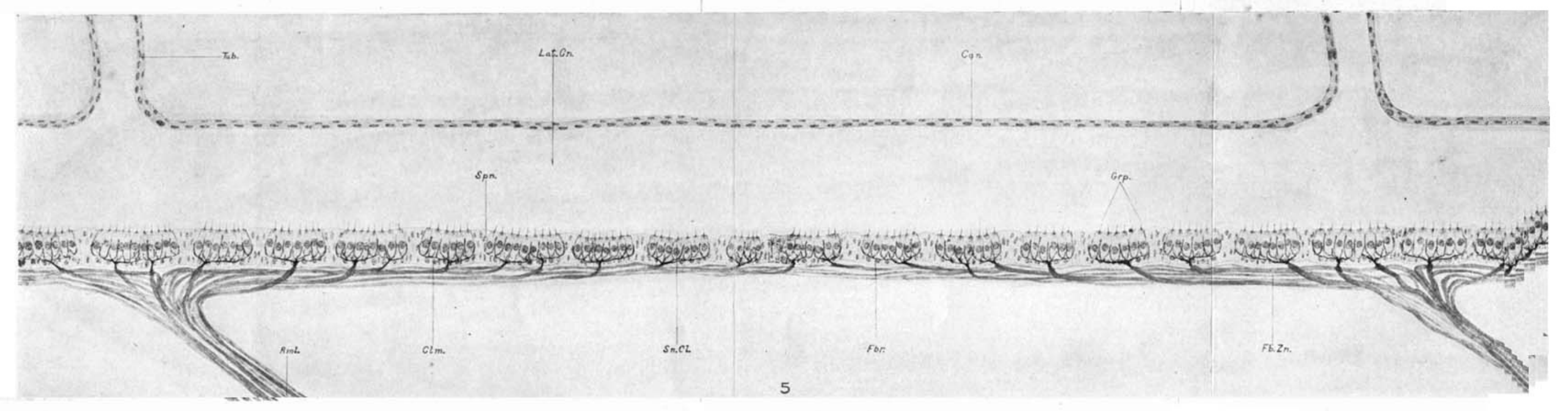

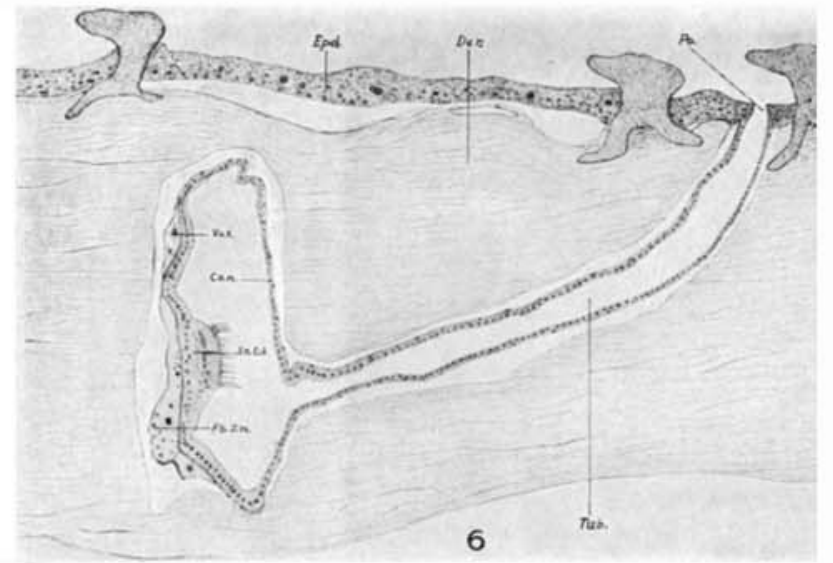

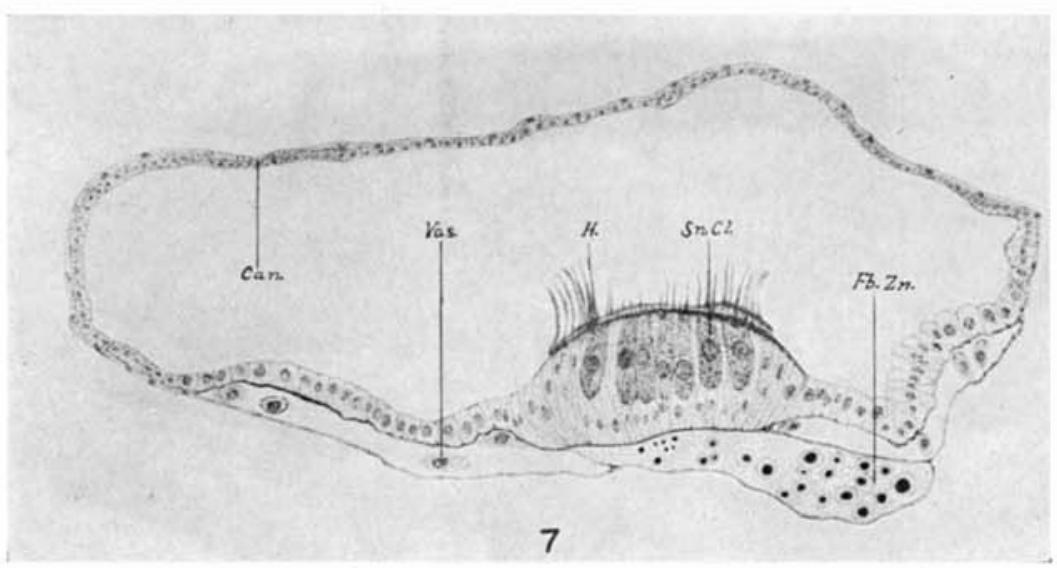

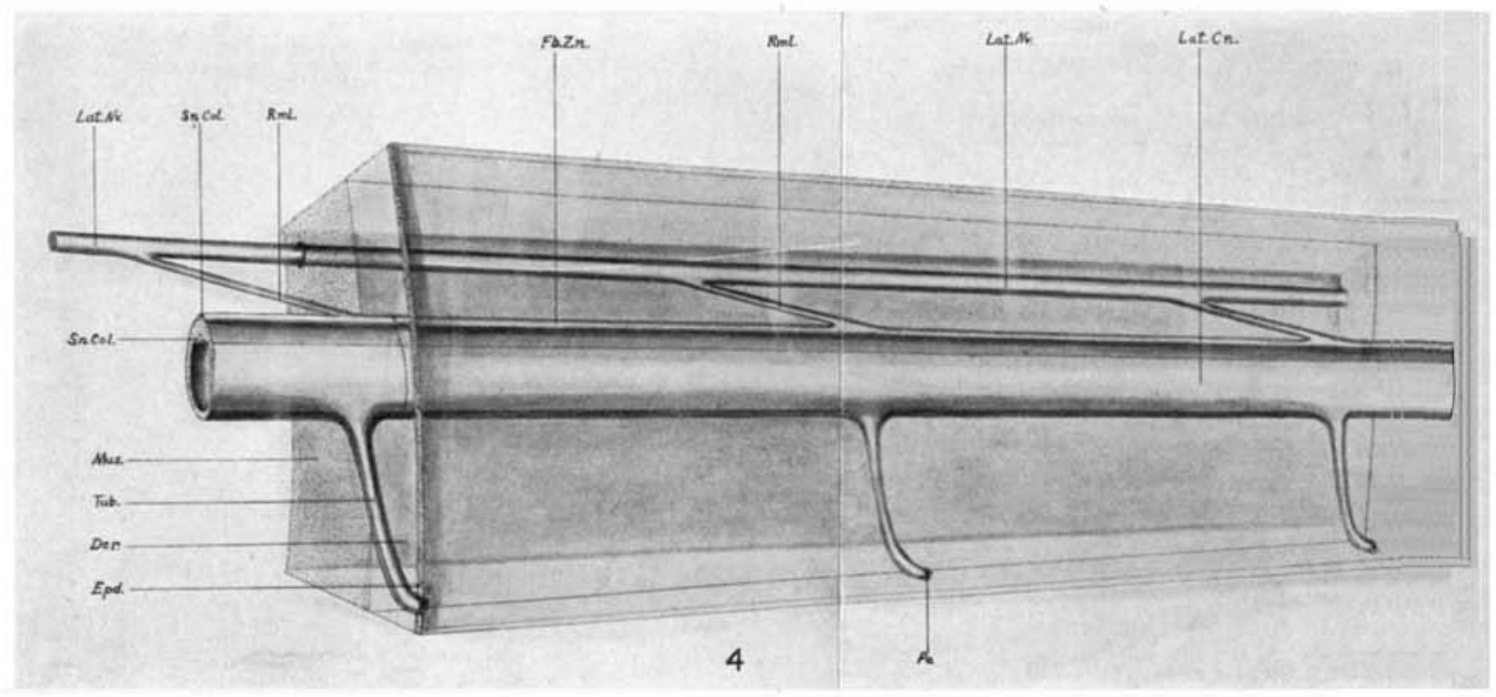


can often be brought out by counterstaining on the slide with Delafield's haematoxylin.

Sections were cut five to fifteen micra and mounted in the usual manner, avoiding, however, solutions not absolutely free from acid.

Terminology. The sense organs of the canal system are distributed in definite lines on the head and trunk of fishes and of amphibians in their aquatic stages. While usually enclosed in a canal, they are sometimes exposed on the surface or in shallow grooves. The lines may be multiple as is common in amphibia and they may reach the number of nine (Herrick).

The terminology employed in this paper is that in common use with the addition of a few terms that conduce to clearness.

The entire system of sense-organs often designated the lateral line system will be called the sensory canal system. This will include all of the canals of the head and the trunk and the surface or pit-organs which are genetically equivalent to the sensory canal organs. As before mentioned, no account is taken of the vesicles of Savi and the ampullae of Lorenzini.

The trunk canal will be called the lateral canal; the head canals will be designated supraorbital, infraorbital, and hyomandibular canals, respectively (figs. 1, 2, 3). The canal running over the temporal region and joining the two lateral canals will be called the supratemporal commissure (figs. 1, 2). Two short detached canals on the lower jaw will be called mandibular canals (fig. 3).

The term sensory canal will be used to denote any of the delicate epithelial tubes, one wall of which is developed into the line of sense-organs, sensory epithelium, or sensory column (figs. 4, 5). The numerous channels connecting the sensory canals with the exterior will be called tubules and their openings on the surface, pores (figs. 4, 6).

With reference to the nerves supplying the sensory canal system, the generally adopted nomenclature will be employed except in the case of the nerve supplying the lateral canal. This will be called simply the nervus lateralis instead of ramus lineae lateralis $\mathrm{X}$. The branches of the N. lateralis which supply 
the supratemporal commissure and the dorsal series of pit organs will be designated supratemporal and dorsal rami of the lateral nerve.

All nerves of the sensory canal system of Mustelus and Squalus occupy a position considerably removed from the canals which they supply. These nerves give off numerous minute branches which in turn make their way through the muscles and connective tissue to the sensory epithelium of the canals. These little branches will be termed the ramuli of the respective nerves (fig. 4).

\section{OBSERVATIONS}

\section{A. MUSTELUS CANIS}

\section{Distribution of the canals and their gross innervation}

The supraorbital canal of the adult may be said to begin a little above the posterior angle of the eye where it is joined by the infraorbital canal (fig. 2). It passes forward above the orbit and a little in front of the latter it descends by a sharp bend to a more ventral position. The canal then passes directly to within a few millimeters of the tip of the snout, where it curves sharply ventralwards and backwards to merge with the infraorbital canal posterior to the nostril (fig. 1). At its anterior extremity the supraorbital canal forms a union with the anterior end of the infraorbital and, as indicated above, a second anastomosis between these two canals is formed posterior to the nostril (fig. 1).

The supraorbital canal has more than a hundred tubules. The tubules vary in length from $0.2 \mathrm{~mm}$. to $1 \mathrm{~mm}$. or more, and the majority of them take a postero-medial course to the surface, where they open in simple pores. An exception to this condition is found about half way between the orbit and the snout. Here the tubules are double and for a short distance many of them branch and anastomose in a complex manner. The significance of this condition is not apparent. It may indicate the fusion of two originally separate canals, or it may rcpresent a modification foreshadowing the complex sys- 
tems of branched tubules (dendritic systems) found in some of the more recent fishes. The former assumption seems improbable in view of the fact that the anlage of the canal is a single cord of thickened extoderm.

The supraorbital canal is innervated by the N. ophthalmicus superficialis VII. This division of the VII nerve, as well as the other nerves which innervate sensory canals, has an individual ganglion near its root and, like these other nerves, it terminates in the same internal nucleus in the tuberculum acusticum (Herrick), or better the area acustico-lateralis.

The infraorbital canal. For descriptive purposes, and on account of its mode of development in Squalus (fig. 53), we may consider the infraorbital as beginning where it unites with the supraorbital. Allis says that in embryos of Mustelus the nerve distribution of buccalis and otic fibers goes back to the supratemporal commissure and on that basis the infraorbital would extend to the supratemporal commissure. Commencing with its point of union with the lateral and supraorbital canals the infraorbital passes ventralwards between the eye and the spiracle, crosses below the eye, and passes forward as far as the anterior margin of the orbit. Here it bends ventrad and slightly caudad, anastomosing with the inferior limb of the supraorbital immediately posterior to the nostril. Slightly anterior to this anastomosis a prebuccal limb of the canal passes antero-medially to the median line on the ventral surface of the head, where it fuses with its fellow of the opposite side. The median canal represented by this union passes forward a short distance and forks into two canals which extend forward and join the supraorbital near the tip of the snout, as mentioned above.

Between the eye and the spiracle the infraorbital canal lies deeper than any of the other canals, having separated completely from the inner surface of the dermis.

The tubules of the infraorbital canal were not all counted, but in number there are considerably over one hundred. On the lateral region of the head the tubules are simple and lead directly to the surface. On the ventral surface of the head, however, most of the tubules are branched or double and open on both 
sides of the canal. The infraorbital receives its nerve supply from the buccalis and oticus facialis.

The hyomandibular canal begins at the ventral angle of the bend of the infraorbital below the eye (figs. 1, 3). The nearly straight canal passes backward to a point beyond the posterior margin of the spiracle. Here it terminates in a slight upward curve. Thirty or more tubules open from the canal to the exterior. Its innervation is from the hyoid division of the $R$. mandibularis externus VII.

Mandibular canals. On each side of the lower jaw is a short mandibular canal (fig. 3). The two opposite canals approach each other anteriorly near the median line, but do not communicate. These canals are innervated by branches of the mandibular division of the mandibularis externus.

The lateral canal (fig. 1) starts from its point of junction with the supratemporal commissure and passes backward in practically a straight line, inclining slightly ventralwards, posteriorly. Over the anal fin there is always a slight but characteristic elevation of the canal for a short distance. Posteriorly the lumen of the canal gradually decreases in diameter, and the tubules become shorter. The lateral canal has approximately 140 tubules and they open to the surface in a line of pores which lies considerably ventrad to the actual position of the canal except near the posterior end, where the tubules are very short and open directly to the surface opposite the canal.

The lateral canal is innervated by the main division of a large nerve, the N. lateralis, which is attached to the side of the medulla oblongata anterior and superior to the first vagus root. It should be noted in reference to figure 1 that the pores and the pit organs are represented as if magnified while the outlines of the fish are reduced.

Supratemporal commissure (fig. 2). A short canal crosses the supratemporal region immediately posterior to the openings of the endolymphatic ducts. This is the supratemporal commissure and it communicates at each end with the lateral canal of that side. In three different specimens 19, 22, and 23 tubules were counted. They average about $1 \mathrm{~mm}$. in length and open 
posteriorly. Innervation is from the supratemporal ramus of the lateral nerve.

Surface organs. In addition to the organs which are enclosed in canals, three lines of pit-organs deserve mention: the dorsal and mandibular series of the adult, and a short line of temporary pit-organs which are found in the pup stages on each side of the scar left by the yolk-stalk.

The dorsal series consists of approximately 80 pit-organs running dorsal to the pores of the lateral line in a somewhat irregular course. In Mustelus (fig. 1) this set or organs extends from a point a little posterior to the eye throughout the length of the body. In Squalus the corresponding set of pit-organs extends only to the region of the first dorsal fin. The nerve supply of these organs comes from a slender nerve which arises from the lateralis ganglion (figs. 45 and 50) and runs nearly parallel to the lateralis nerve.

The mandibular series of the adult contains approximately 45 sense organs. They begin at the posterior margin of the spiracle and then curve backward around the end of the hyomandibular canal and forward reaching nearly to the median plane (fig. 3). The innervation of this line of organs has not been determined.

The two short lines of surface organs situated on opposite sides of the yolk-stalk appear to be very poorly developed (fig. 3). Each line contains 9 or 10 organs. These organs have not been observed in the adult and their innervation is unknown.

\section{Structure of the sensory canals}

a. General anatomy. The delicate tubes of the sensory canals in Mustelus have walls consisting of two layers of epithelial cells, except on the dorsal side, where the canal wall is greatly thickened into a ridge of sensory epithelium (figs. 4, 6, 7). The diameter of the canals varies in different parts of the body as well as in specimens of different size. The average diameter of the head canals is about $0.3 \mathrm{~mm}$. in a specimen two feet long, while in the same specimen the trunk canal varies from about $0.2 \mathrm{~mm}$. at its anterior end to $0.08 \mathrm{~mm}$. or less posterior to the 
caudal peduncle. Even in large adults the lateral canals terminate in open grooves on the sides of the caudal fin.

Figure 4 is a diagram to show the relations of sensory canal, surface tubules, lateral nerve and its ramuli. The ramuli of the nerve as well as the tubules have been much foreshortened in order to bring them within the limits of the diagram.

The sensory epithelium of the lateral canal of Mustelus forms a column that is substantially continuous throughout the length of the canal (figs. 5, 6, 7, 8). It is not divided into segments corresponding to the metameres of the trunk. This sensory column occupies the dorsal wall of the canal. It is two or three cell layers in thickness and it is in this sensory column that we find the development of sensory cells that are called the sense organs of the lateral line. Figure 5 is a semi-diagrammatic sketch of the sensory column between two tubules. There are 16 elusters of cells (outlined with the camera) between the two tubules. The ramuli of the nerves correspond to the tubule and the nerve fibers overlap.

The thickness of the lateral sensory column is not constant throughout its length, but becomes gradually thinner posteriorly (figs. 9, 10,11). It is also thinner as a rule midway between two ramuli of the lateral nerve. This may indicate a tendency for the sensory column to assume a segmental character, but in no instance in Mustelus has the sensory column been observed to be completely divided into separate 'buds' or segments, as appears to be the condition in Amia and several other forms.

On each side of the lateral sensory column are large blood spaces and the adjacent columnar epithelium of the canal wall is considerably thickened (fig. 8). Little tubules lead from the canals to the surface of the integument at approximately regular intervals. Their walls are composed of two layers of epithelial cells which are continuous with those of the inferior wall of the canal (fig. 6). The tubules coincide in number with the ramuli of the lateral nerve and they do not increase in number after the canals have closed. A hundred and thirty-six tubules were counted in the lateral canal of a specimen $55 \mathrm{~mm}$. long, while 
a specimen $300 \mathrm{~mm}$. long had a hundred and thirty-eight. In the adult the tubules do not lead in a direct path to the surface, but pass postero-ventrally for the distance of $1 \mathrm{~mm}$. or less and then bend laterally, passing through the epidermis and opening to the exterior near the base of a slightly modified scale (fig. 6). In the posterior region of the body the tubules are much shorter and take a more direct course to the surface.

The sensory canals may be said to occupy 'dermal tunnels' which, on the trunk, lie within the dermis, but on the head most of the canals sink to a somewhat deeper level.

b. Histology of the sensory epithelium. The sensory epithelium of the lateral canal is limited to a narrow ridge or column which forms the greater part of the dorsal wall of the canal. As mentioned before, this column of sensory epithelium is practically unbroken throughout the length of the canal except for a great many minute transverse ridges. These ridges are usually a little less than $0.1 \mathrm{~mm}$. apart (in a 2 foot specimen) and mark the spaces between the groups of hair-cells. The sensory column varies considerably in thickness from the anterior to the posterior end of the canal, and usually presents a marked depression between consecutive ramuli of the lateral nerve. This is not invariably the condition, however, for in many preparations the sensory epithelium is as thick between the ramuli as it is elsewhere (fig. 5).

Four different kinds of cells have been distinguished in the sensory column: (1) hair-cells; (2) basal cells; (3) spindle-shaped supporting cells; (4) columnar supporting cells.

The hair-cells are arranged in clusters and are considerably larger than the other cells. They are somewhat club-shaped, their proximal ends being greater in diameter than their distal ends. The nuclei are large, round, and centrally located as a rule. In suitable preparations hair-like processes always appear at the distal ends of these cells (figs. 7, 8). Whether there is a single process on each cell, or whether there are several clumped together by reagents so that they appear as one could not be determined, but the evidence is in favor of the view that there is a single 'hair' on each cell (figs. $7,8,9,11$ ). The hair-cells 

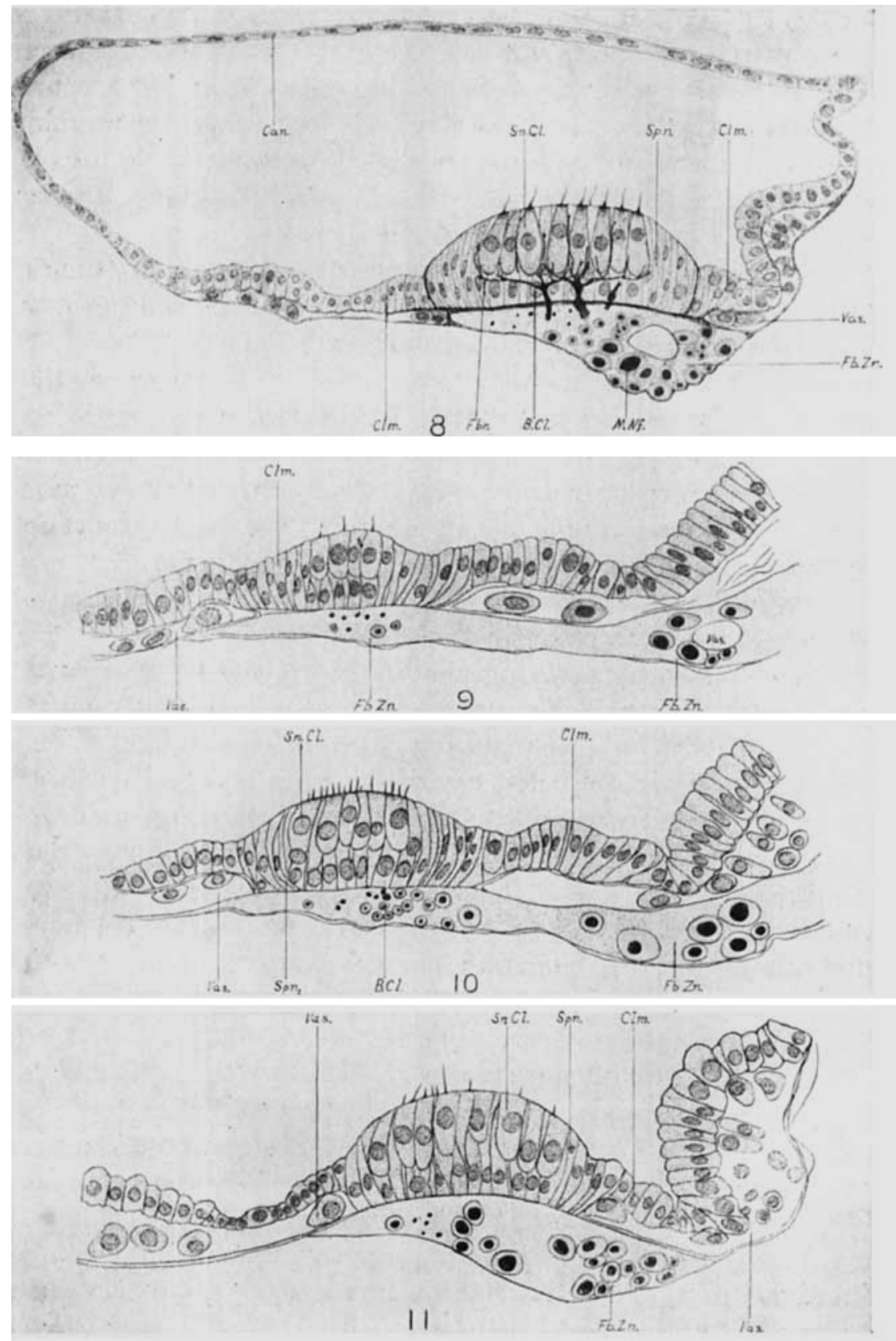
are not the same size throughout the length of the sensory column, but are considerably smaller in the posterior region (figs. $9,11)$. They extend through about two-thirds the depth of the sensory column, and their distal ends abut against a limiting membrane which presents a great deal of variation in thickness in different preparations.

Basal cells. The boundaries of the basal cells are usually difficult to trace, except their proximal margins, which rest on a well developed basilar membrane. The cells usually appear somewhat triangular in shape and they extend distally between the proximal ends of the hair-cells. 'Their nuclei are round, centrally located, and frequently appear almost as large as the nuclei of the hair-cells (figs. 9, 11).

The spindle-shaped cells. These cells occur between and around the hair-cells (figs. 8, 9 to 12). They are very slender and greatly elongated, extending from the basilar membrane to the distal limiting membrane of the sensory column. The nuclei are small, much elongated, and are located near the proximal ends of the cells except in cells which lie immediatly between two adjacent clusters of hair-cells; in these the nuclei are near the distal ends of the cells (fig. 5).

Columnar cells. The columnar cells are the most numerous of all the cells in the sensory column. They extend from the basilar membrane to the distal limiting membrane and vary in length with the variation in thickness of the sensory column (figs. 9, 10). On each side of the sensory column proper the columnar epithelium becomes thinner and merges gradually into the thin, inner epithelial layer of the sensory canal (figs. 7, 8).

Fig. 8 Transverse section of lateral sensory canal, showing the histological structure of the sensory column, peripheral nerve terminations, and the longitudinal fiber zone (of nerve distribution). The figure was drawn with the aid of a camera lucida from a pyridine silver preparation counterstained with Delafield's haematoxylin. Mustelus canis garter. $\times 370$.

Figs. 9, 10, 11 Transverse sections of the lateral sensory column of a small adult Mustelus canis, showing that, posteriorly, the sensory epithelium is considerably less extensive than anteriorly. Figure 11 was taken anterior to the first dorsal fin; figure 10, between the first and second dorsal fins; and figure 9 , posterior to the second dorsal fin. $\times 370$. 
The nuclei of the columnar cells are small, round or elongated, and are located at various levels in the cells.

Cross sections show that for a short distance on each side of the sensory ridge the columnar epithelium is considerably modified and thickened where it overlies rather large longitudinal blood spaces (fig. 8). In many preparations some of the cells in this region present full, rounded outlines, while others appear greatly shrunken and vacuolated. The difference in appearance of these cells under like treatment and their proximity to an abundant blood supply suggests that they may have a secretory function.

The basilar membrane appears as a structureless sheet from 0.5 to 1 micron in thickness. It separates the sensory epithelium from the longitudinal fiber zone, the blood capillaries and other neighboring tissues.

c. Peripheral terminations of the nerous lateralis. Demonstration of the precise nature of the peripheral terminations of the lateral nerve has been one of the most difficult tasks in connection with the study of the sense organs of the lateral canal system. The earlier investigations on nerve terminations took place before the introduction of silver impregnation, of methylen blue, and of other modern methods. Retzius '92 and von Lenhossék '92-'93 made numerous impregnations by Golgi methods but they were unable to demonstrate the terminal fibers of the lateral nerve. They expressed the belief, however, that the nerve fibers ended, not in the hair cells, as Leydig believed, but in free fibrillations in the sensory epithelium.

Later investigators have held, largely, to the ideas expressed by Retzius and von Lenhossék. Johnston '06 says that the lateral nerve ends in complex fibrillations between the haircells of the sense-organs. His statement, however, is based on a brief unillustrated paper on the lateral sense organs of Ameiurus by F. S. Bunker ' 97 . Heilig '12 worked on the peripheral terminations of the lateral nerve in a species of perch, but his histological illustrations are not completely satisfactory. His figures show the nerve fibers approaching the bases of the haircells, but their relation to the cells is not shown. 
As far as I am aware no observations have been published on the peripheral terminations of the lateral nerve in selachians and, as indicated above, the work on other forms has not been entirely satisfactory. The following account is based on the study of a great number of preparations made from successfully impregnated sensory epithelium from the lateral canal of Mustelus canis. In order to disclose all possible relations, sections were cut transversely, obliquely, and longitudinally, to the long axis of the canal, and a few were cut in a plane at a right angle to the long axis of the hair-cells.

It has already been stated that each ramulus of the lateral nerve approaches the sensory canal obliquely (figs. 4, 13) and that the sensory column is developed on the medial superior wall of the canal. What is spoken of as the base of the sensory column is thus directed towards the superior boundary wall of the sensory canal (fig. 6).

Each ramulus of the N. lateralis is composed of eighteen to thirty or even more nerve fibers, varying in diameter from one to six micra (figs. 14, 15). The majority of the fibers are medullated and they are bound together by a comparatively thick connective tissue sheath. Upon reaching the base of the sensory column the outer sheath of the ramulus merges into the dermal tissue surrounding the sensory canal and the nerve fibers then pass in both directions, i.e., caudad and cephalad, along the sensory column outside the basilar membrane (fig. 5). The nerve fibers from adjacent ramuli overlap for a short distance on the base of the sensory column. A continuous and well-marked fiber zone is thus formed which extends throughout the length of the sensory column. Naturally this fiber zone is largest where the ramuli first reach the canal, and smallest approximately midway between two adjacent ramuli, where fibers from each territory overlap for a short space (figs. 5, 12). In no case has a complete break in the continuity of the fiber zone been observed. This condition is similar to an old sketch of Hexanchus griseus published in 1859 in Leydig's Lehrbuch der Histologie. 

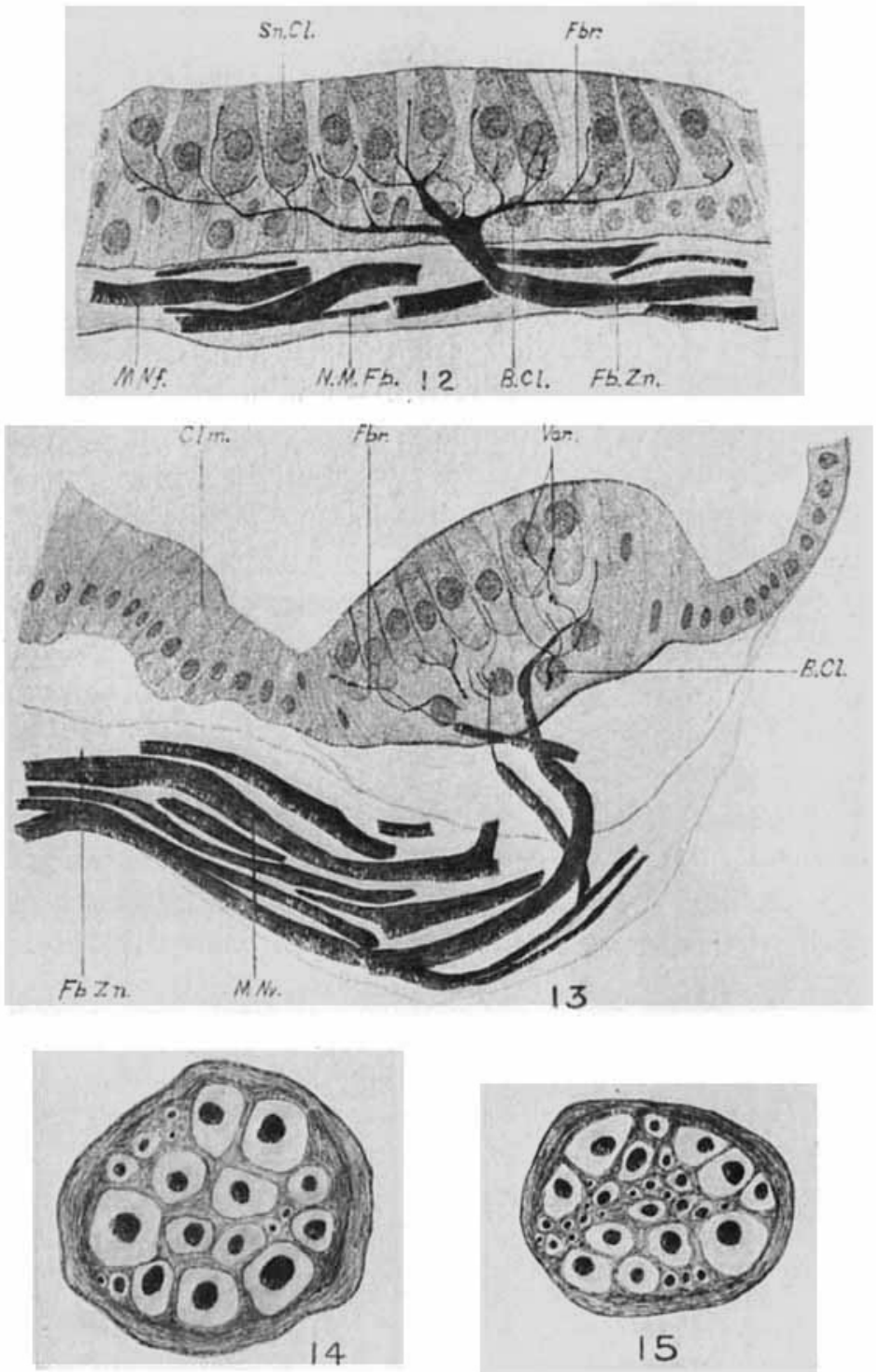

Fig. 12 Longitudinal section through one group of 'hair-cells' showing the extensive branching of fibrillae from one nerve fiber. Wustelus canis adult. (Pyridine silver and Delafield's haem.) $\times 565$.

Fig. 13 Oblique section of the lateral sensory column, showing the lateral ramulus and several varicosities on the terminal fibrillae. Mustelus canis adult. (Silver-pyridine tech.). $\times 555$.

Figs. 14, 15 Transverse sections of lateral ramuli, showing variation in the number of fibers as well as in the size of the individual fibers. Mustelus canis adult. Figure 15 represents a silver-pyridine preparation; figure 16 , a Delaficld haematoxylin preparation. $\times 555$. 
The usual manner of distribution of the nerve fibers to the groups of hair-cells is shown in figure 5. The fibers run along the basement membrane until they reach points beneath the particular groups of hair-cells which they innervate. Here they usually make a sharp bend and, losing their medullary sheaths, they penetrate the basement membrane (fig. 13), but in several cases they are seen to divide into two or more primary divisions while still outside of the sensory epithelium (figs. 17, $20,21)$. The nerve fibers may divide at a variety of levels between the longitudinal fiber zone and the bases of the hair-cells. As a rule the finer fibers pass deeper into the sensory epithelium before dividing than the larger ones, but fibers of intermediate sizes are seen dividing at various levels between the basement membrane and the hair-cells. The primary branches of a single nerve fiber separate rather widely, and as seen in longitudinal section (fig. 12) they may cover approximately the base of one group of hair-cells. These branches divide repeatedly, often into extremely fine fibrillae which pass freely between the adjacent walls of the hair-cells to a distance ranging from about onefourth to three-fourths or more of the length of the hair-cells (figs. 13, 16, 20). In a great number of cases the fibrillae are seen to terminate in little rounded enlargements or end-knobs, and varicosities of similar appearance occur at various levels on many of the terminal branches (figs. 13, 19). The largest are often seen at points of primary division and in some cases resemble the terminal enlargements of the ampullae of the ear described by Mullenix (1910) as 'calyses', though they do not bear the same relationship to the hair-cells as Mullenix has suggested they do in the auditory epithelium of Fundulus.

No cup-like expansions or close anastomosing networks around the bases of the hair-cells have been observed. The appearance of such conditions in the auditory epithelium, as reported by some investigators, seems likely to have been due to overstaining or over-impregnation, with resulting irregular deposits of silver between the finely dividing fibrillae.

The general similarity between the canal organs and those of the internal ear makes the nature of the terminations of the 
eighth nerve of interest in this connection. A. D. Morrill, in a very exact piece of work, found conditions in the auditory epithelium of Mustelus which correspond very closely to the conditions here described for the sensory epithelium of the lateral canal, and from the morphological evidence now at hand it seems fairly safe to conclude that the peripheral terminations of the lateral and acoustic nerves are essentially alike, and that these terminations are not, in the nature of 'cups,' 'calyses,' or
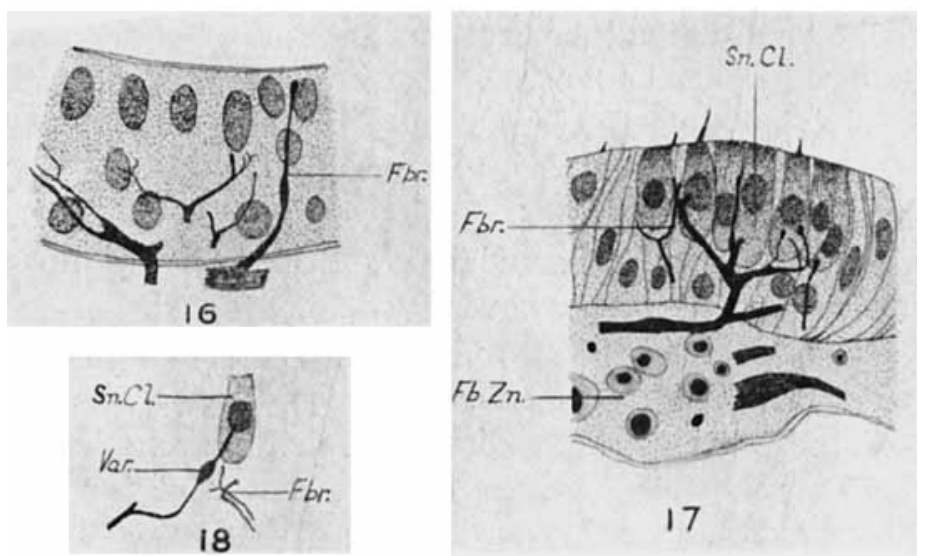

lig. 16 Longitudinal section of the lateral sensory column showing free nerve terminations. Justelus adult. Silver-pyridine teeh. $\times 555$.

a. Fig. 17 Longitudinal section of sensory epithelium showing fiber zone, free terminations embracing bases of 'hair-cells,' and varicosities on fibrillae. Mustelus adult. Silver-pyridine tech. $\times 55.5$.

Fig. 18 'Hair-eell' and fibrillae bearing an unusually large varicosity. Mustelus adult. Silver-pyridine tech. $\times 555$.

complex anastomosing networks, but that the nerves terminate in numerous delicate fibrillae which surround the bases of the hair-cells to a greater or less degree, and penetrate freely and sererally between the walls of the hair-cells.

\section{Development of the sensory canals of Mustelus}

A complete series of Mustelus embryos could not be procured and accordingly more detail of development will be brought out in the following division of this paper dealing with Squalus 

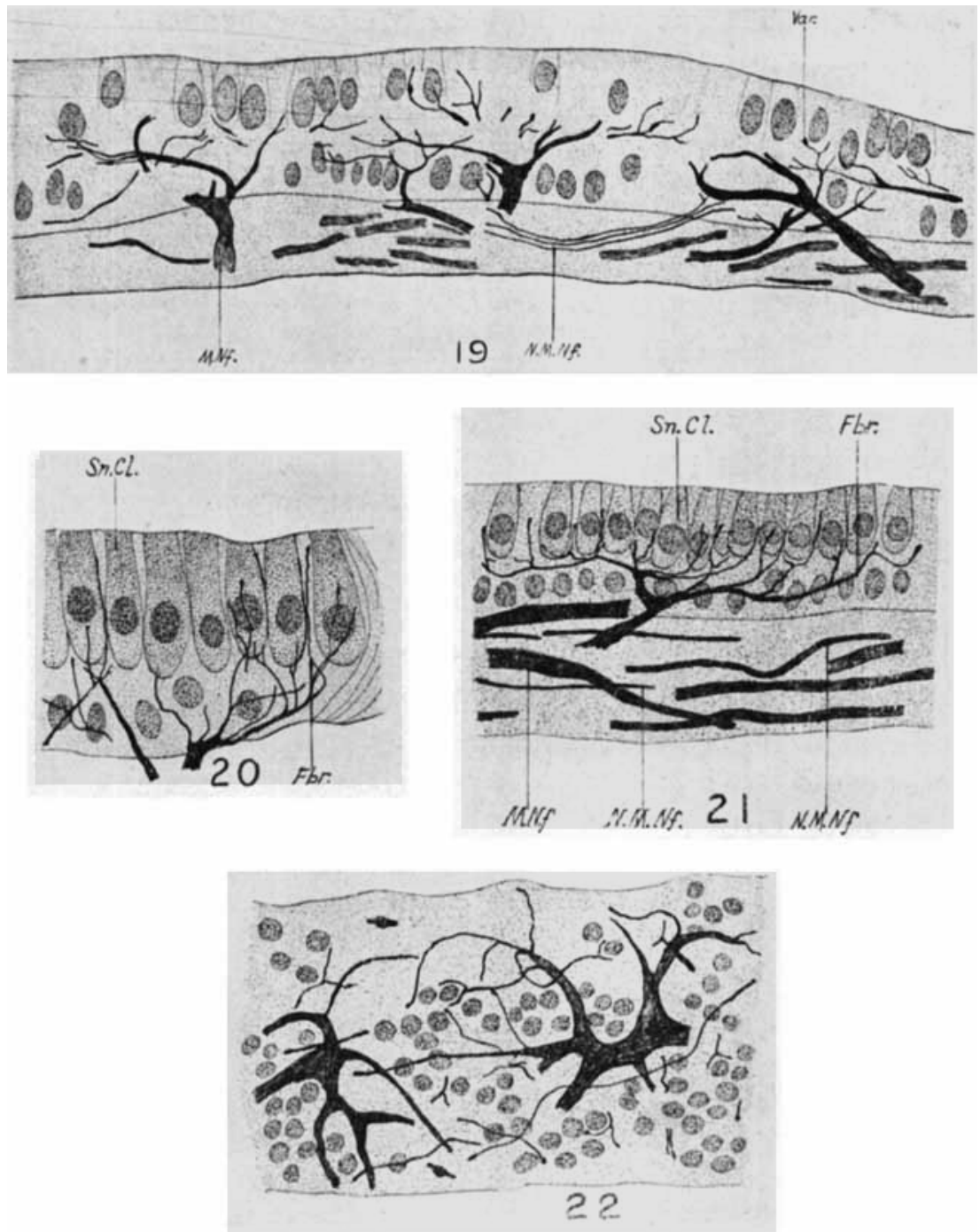

Fig. 19 Longitudinal section of the sensory column and zone of nerve distribution. Mustelus adult. Silver pyridine tech. $\times 444$.

Fig. 20 Longitudinal section of the sensory column showing very long and delicate fibrillations. Mustelus adult. Silver-pyridine tech. $\times 592$.

Fig. 21 Longitudinal section of lateral sensory column showing wide distribution of fibrillae. Non-medullated fibers are to be seen in the fiber zone. Mustelus adult. Silver-pyridine tech. $\times 440$.

Fig. 22 Section of lateral sensory epithelium cut at right angles to long axis of the secondary sensory cells. Cell boundaries could not be seen. Mustelus adult. Silver-pyridine tech. $\times 440$. 
acanthias. The earliest stages of Mustelus available and in usable histological condition were $40 \mathrm{~mm}$. in length. In these the head canals and their nerves are already formed. The lateral canal reaches to within 3 or $4 \mathrm{~mm}$. of the caudal extremity and for a few millimeters in this region it has not yet closed, but is still in the form of an open groove.

The closure of the canal. There are no important differences in the method of canal formation in Mustelus and squalus. It is essentially a process of the formation of a tube from an invaginated groove, though this fact is considerably obscured by irregularities due to unequal growth. As the lateral surface thickening grows posteriorly a groove appears on its surface and extends from the anterior end, where it first appears, posteriorly, lagging considerably behind the growing end of the thickening. As growth continues the groove becomes deeper and longer. It the same time the sensory epithelium is differentiating into a thickened ridge. Over this ridge the lips of the groove approach each other in short sections. Between the sections openings remain which become the canal tubules of the adult. The lips opposite each other fuse first at their central points so that the openings between the points of fusion appear, in the early stages of fusion, as longitudinal slits. In a specimen $55 \mathrm{~mm}$. long the canal is closed to within a few millimeters of the caudal extremity. The surface openings near the end of the closed part of the canal, however, are still in the form of elongated slits. Passing forward the slits become gradually shorter until, below the second dorsal fin, they are minute, circular openings, which is their normal condition in the adult (fig. 23).

For a considerable length of time after the lateral canal is formed its lumen remains very small, in some cases appearing to be almost obliterated. Careful examination, however, always reveals its presence, although the inner walls of the canal may be nearly in contact with each other (figs. 24, 25). In these early stages the lumen of the canal must have been overlooked by Balfour as he held the opinion that it was formed by a lumen appearing in a solid cord of cells. 

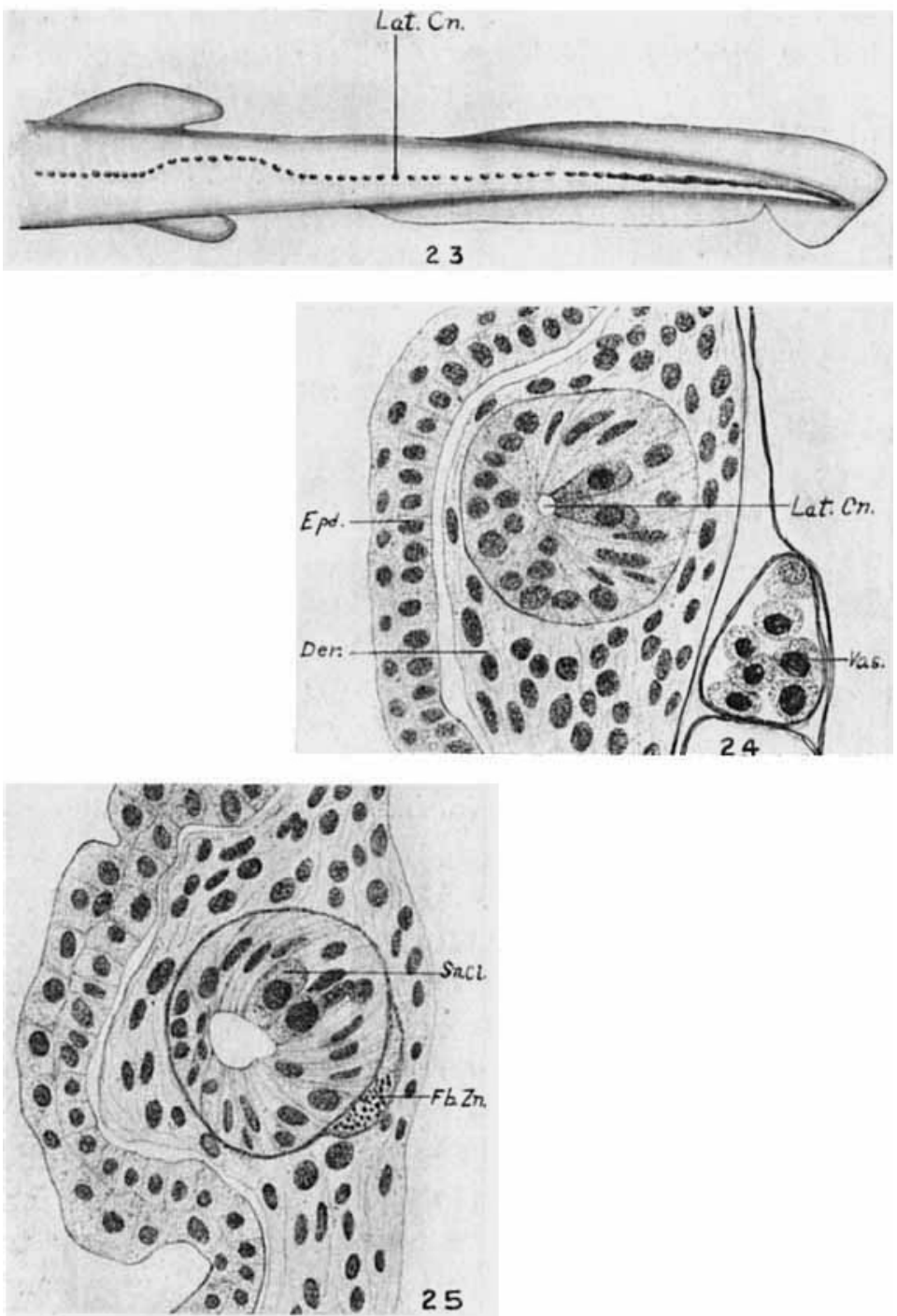

Fig. 23 Caudal end of a $55 \mathrm{~mm}$. Mustelus embryo. Note that the pores of the tubules become larger and somewhat elongated posteriorly to the point where the canal merges into an open groove. $\times 4 \frac{1}{2}$.

Fig. 24 Transverse section, lateral canal of a $65 \mathrm{~mm}$. embryo, posterior to first dorsal fin. Note the small lumen. Mustelus $\times 592$.

Fig. 25 From the same specimen as figure 24, but farther cephalad, where the lumen of the canal is much larger. 
In specimens 65 to $70 \mathrm{~mm}$. long the entire sensory canal system is completely mapped out. The canals are all closed and have reached their ultimate distribution, though in subsequent stages they become somewhat greater in diameter and, on the head, sink deeper in the integument, or even to a depth beneath the integument.

The differentiation of the sensory epithelium could not be studied in Mustelus owing to the lack of sufficiently early stages.

B. SQUALUS ACANTHIAS

\section{Development of the sensory canal system}

a. Early stages of development -9 to $36 \mathrm{~mm}$. In tracing the development of the canal system of Squalus it will be convenient to consider the matter under two heads: (a) early stages of development, from the first definite appearance of sensory cords on the surface to the time the lateral cords have grown back to the tail, and (b) later stages of development, involving involution of the sensory cords, the closure of the canals and the differentiation of the sensory epithelium. For observations of the earlier stages I had embryos between 9 and $36 \mathrm{~mm}$. body length and for the later stages those from 40 to $72 \mathrm{~mm}$. The descriptions are confined chiefly to the development of the lateral cord and canal, since their growth is typical of the corresponding structures of the head, simpler for examination and not complicated by cephalic modifications.

Material was not available for independent study of the first phases of development of the canal system, but sketches of Squalus embryos from 3.25 to $8 \mathrm{~mm}$. length made under the direction of Professor Locy by Mr. Otto Swezey seem to indicate that the epithelium of the sensory cords has a common origin with the epithelium of the ear. In tracing the primordia of the lateral line organs two things are to be kept in mindthe epithelium out of which the sensory cords are developed and the primordia of the ganglia. One comes from the surface ectoderm and the other from the neural crest. While the ganglia arise independently, the sketches of Mr. Swezey appear 
to favor the conclusion that the thickened patches of the sensory cords were originally a part of the auditory thickening and such was the interpretation of Mr. Swezey.

It must be said, however, that my observations on the relation of the primordia to the auditory thickening are not of a definite character and, as a result, they do not throw light on the question of the independence of origin of the primordia of the lateral line system and of the auditory epithelium (Landacre '10, Reed '16).

My own observations of developmental stages began with embryos $9 \mathrm{~mm}$. in length. In this stage definite rudiments of the lateral sensory cords had appeared as well as of the principal canals of the head. In a $36 \mathrm{~mm}$. embryo the lateral sensory cord of the trunk has reached the tail region and the distribution of the sensory cords of the head, although not in their final arrangement, are so clearly outlined that the different lines can be easily defined.

Nine millimeter stage. The $9 \mathrm{~mm}$. embryo, the head of which is shown in surface view in figure 26 , has about sixty somites. The cranial ganglia from the fifth backwards are well developed and can be seen in surface view as elevations of more or less prominence. The ninth nerve, which may be adopted as a landmark, can be identified by its ganglion just behind the ear capsule and a long process extending from the ganglion into the first branchial arch.

Immediately posterior to the ninth are the lateralis and vagus roots, the latter connecting with the walls of the medulla in a broad sheet. The distal margin of this sheet exhibits, at this stage, three ganglionic enlargements that lie above the second, third and fourth branchial arches and have a placode connection with the thickened ectoderm.

A dissection of this region shows that the ganglion of the lateralis nerve is independent of the vagus. It is attached anterior to the vagus roots (figs. 27,30 ) and crosses obliquely the expanded sheet of the vagus rootlets (fig. 30).

A cross section (fig. 28) taken through the plane of the line $\mathrm{A}-\mathrm{B}$ of figure 27 shows the structure of the lateralis ganglion 

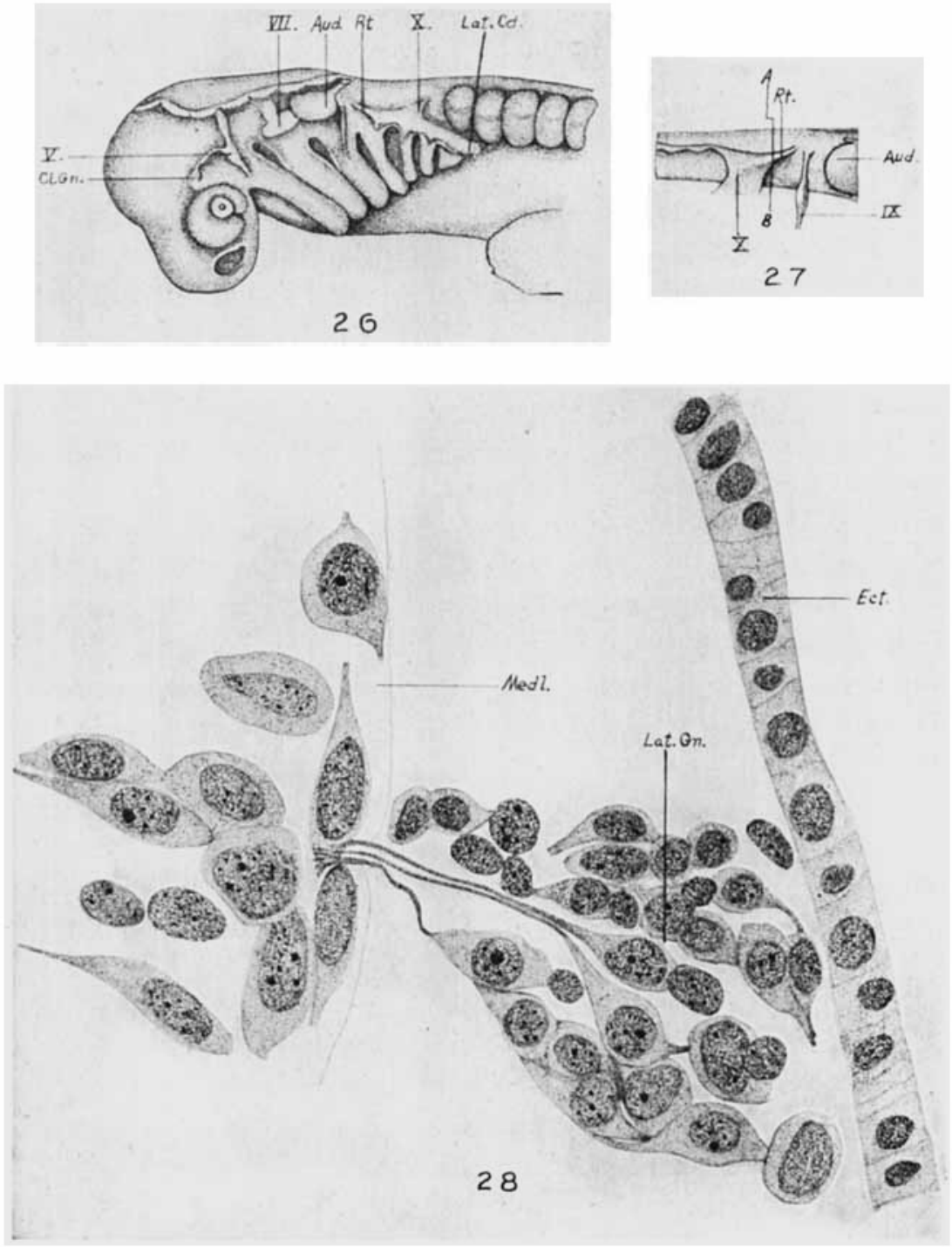

Fig. 26 Squalus acanthias. Surface view of a $9 \mathrm{~mm}$. embryo. $\times 13$. From a sketch by Otto Swezey.

Fig. 27 Lateral dissection of a $9 \mathrm{~mm}$. specimen showing the roots of the ninth, the lateralis, and the vagus nerves. $\times 20$.

Fig. 28 Transverse section through the region indicated by the line $A-B$ in figure 27 . Squalus. $\times 976$. 
and its connection with the brain wall. At this stage the ganglion cells are of the bipolar type and the section shows three central processes penetrating the wall of the medulla. The peripheral processes run obliquely backwards toward the cells of the ectodermal anlage of the lateral sensory cord.

Eleven millimeter stage. This stage (fig. 29) shows well marked advances in the development of cranial structures. Confining attention to the vagus and lateralis region, surface observations show the widely expanded sheet of vagus rootlets merging on the ventral margin into three well marked vagus ganglia. The lateralis ganglion is connected with the brain wall in front of this widely expanded sheet and the ganglion itself passes obliquely backwards over the sheet of rootlets and above the vagus ganglia. This is shown better in the dissection of this region of a slightly older embryo (fig. 30). The independence of the lateralis ganglion is clearly shown in this sketch and sections confirm this independence, although its ganglion cells and those of the vagus are closely associated in some of the sections. Distally the fibers arising from the ganglion cells of the lateralis pass out among the growing cells of the ectodermal cord. The terminals of the peripheral fibers end freely among the cells and have not as yet established dendritic relations with cells of the ectodermal cord. The condition is shown in a little later stage of development in figures 35 and 36.

In the $11 \mathrm{~mm}$. stage the ectoderm at the growing end of the lateral sensory anlage is crowded with dividing cells which lie next to the surface (fig. 31) and the cells of this thickening are enlarged or elongated.

Thirteen millimeter stage. The sketch of this stage (fig. 32) is copied from a drawing by Mr. Otto Swezey. Four gill-slits have broken through and fringes of external gills are beginning to appear. Owing to thickening of the adjacent tissues, the cranial ganglia and their roots are not so clearly discernible from the exterior.

Two small thickened cords of ectoderm fork in front of the facial ganglion. One is directed above and the other below the 

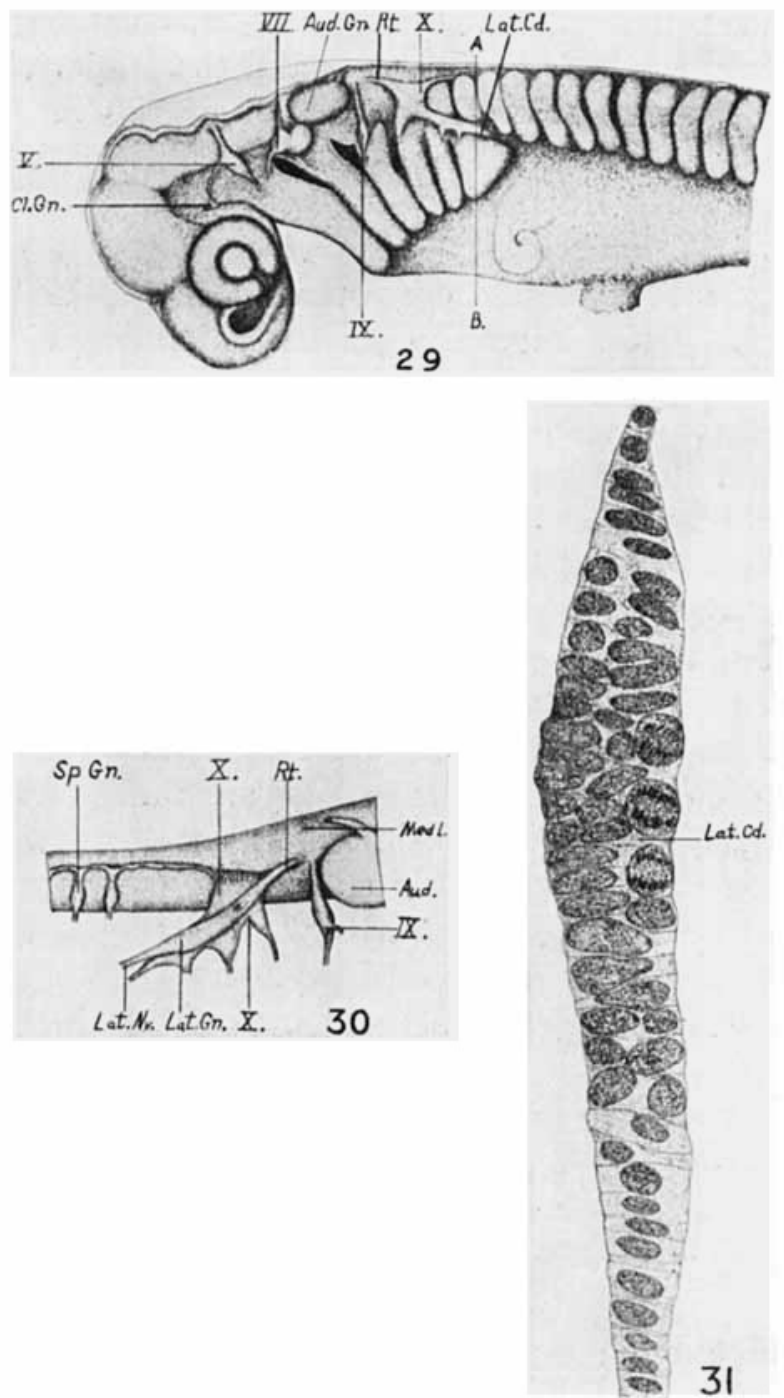

Fig. 29 Surface view of an $11 \mathrm{~mm}$. embryo showing the various structures concerned in the formation of the sensory canal system. Squalus. From a sketch by Otto Swezey. $\times 16$.

Fig. 30 Lateral dissection of the medulla spinalis showing early separation of lateralis root and ganglia from the vagus complex. Squalus, $11 \mathrm{~mm}$. $\times 20$.

Fig. 31 Transverse section of the thickened ectodermal cord at position indicated by line $A-B$ in figure $29 . \times 466$. 
eye. These cords represent the rudiments of the supraorbital and the infraorbital sensory canals. Nerve fibers from two ganglionic enlargements of the seventh are distributed among the cells of the inner surface of the growing cords. The superior bundle of fibers is the rudiment of the ramus ophthalmicus superficialis VII and the inferior bundle the rudiment of the ramus buccalis VII. The cord of the lateral canal is obviously longer than in the earlier stages.

Fifteen millimeter stage. Surface observations of this embryo (fig. 33) show considerable growth of the sensory cords. The supraorbital and the infraorbital are longer and better defined. The nerve bundle of the infraorbital cord has begun at its proximal end to sink beneath the inner surface of the cord.

The lateral cord has increased in length and also in thickness. A new feature has made its appearance at the distal end of the cord in the form of an ectodermal fold (fig. 33, Ep. Po.) which at first is a shallow pocket, and in later stages becomes a tunnel. The condition produced is as if the distal end of the cord in growing backwards had pushed under the common ectoderm lying in its path, causing the latter to bulge into a crescentshaped fold. A longitudinal section of this fold is shown in figure 36 .

A dissection of the region back of the ganglion of the ninth nerve is shown in figure 34 . The lateralis ganglion and its roots are now easily distinguishable from the ganglia and roots of the vagus. The vagus roots enter the brain wall in a continuous broad sheet and the inferior margin is separated into four distinct ganglia. The lateralis ganglion crosses the vaguscomplex running obliquely above the four ganglionic enlargements. It is greatly elongated, its distal end reaching posterior to the fourth vagus ganglion.

Longitudinal sections of this stage show the nature of the growth of the lateralis nerve and the relation of its fibers to the cells of the sensory cord. Figure 35 represents part of a section taken lengthwise through the lateralis ganglion. The ganglion (Lat. Gn.) is composed chiefly of bipolar cells the central fibers of which pass into the brain (fig. 28). The peripheral 

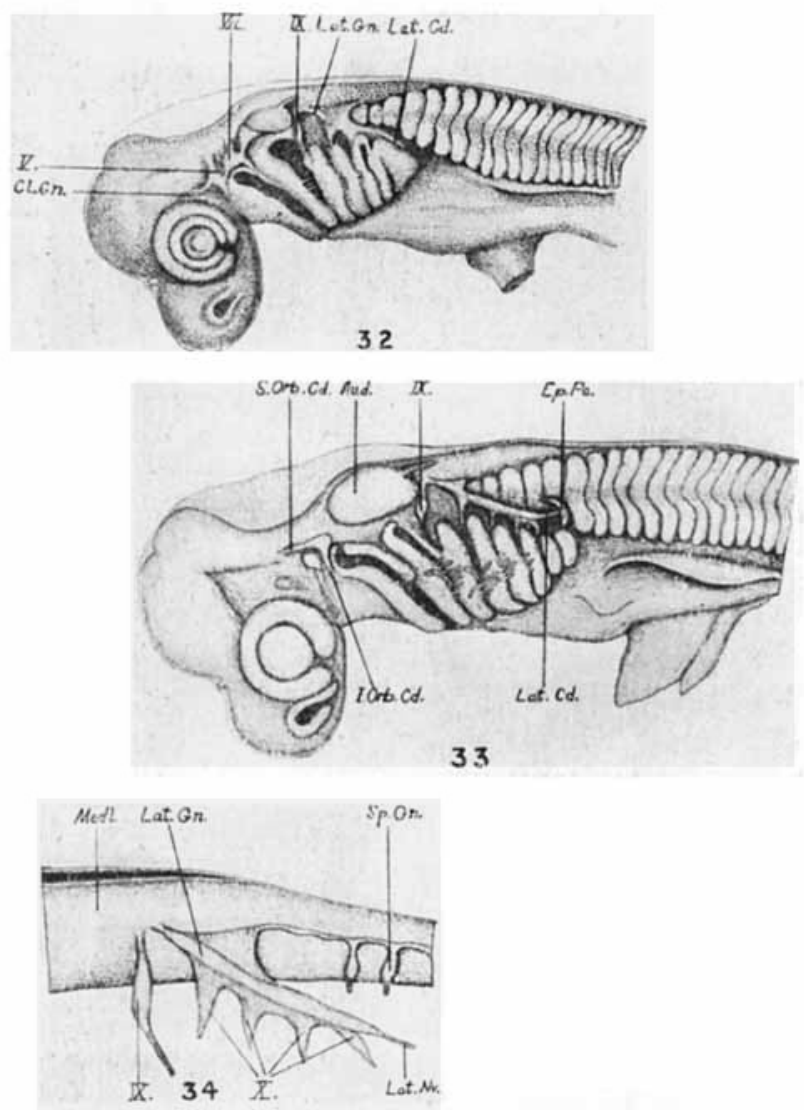

Fig. 32 Surface view of a $13 \mathrm{~mm}$. embryo. Squalus acanthias. From a sketch by Otto Swezey. $\times 10$.

Fig. 33 Surface view of a $15 \mathrm{~mm}$. specimen. Note the epidermal pocket at the growing end of the lateral eord. Squalus acanthias. From a sketch by Otto Swezey. $\times 10$.

Fig. 34 Lateral dissection of the medulla of a $15 \mathrm{~mm}$. embryo of Squalus showing roots and ganglia of the lateralis and vagus nerves. $\times 20$.

Fig. 35 Horizontal section through the posterior part of lateralis ganglion, showing fibers from the ganglion cells cxtending into the thickened ectoderm of the lateral cord. Squalus, $15 \mathrm{~mm}$. specimen. $\times 492$.

Fig. 36 Horizontal section, from the same specimen as figure 35 , but taken at the growing end of the lateral sensory cord. Shows the epidermal fold over the greatly enlarged growing end of the sensory cord; nerve fibers extend among the cells of the latter. Squalus, $15 \mathrm{~mm} . \times 492$. 

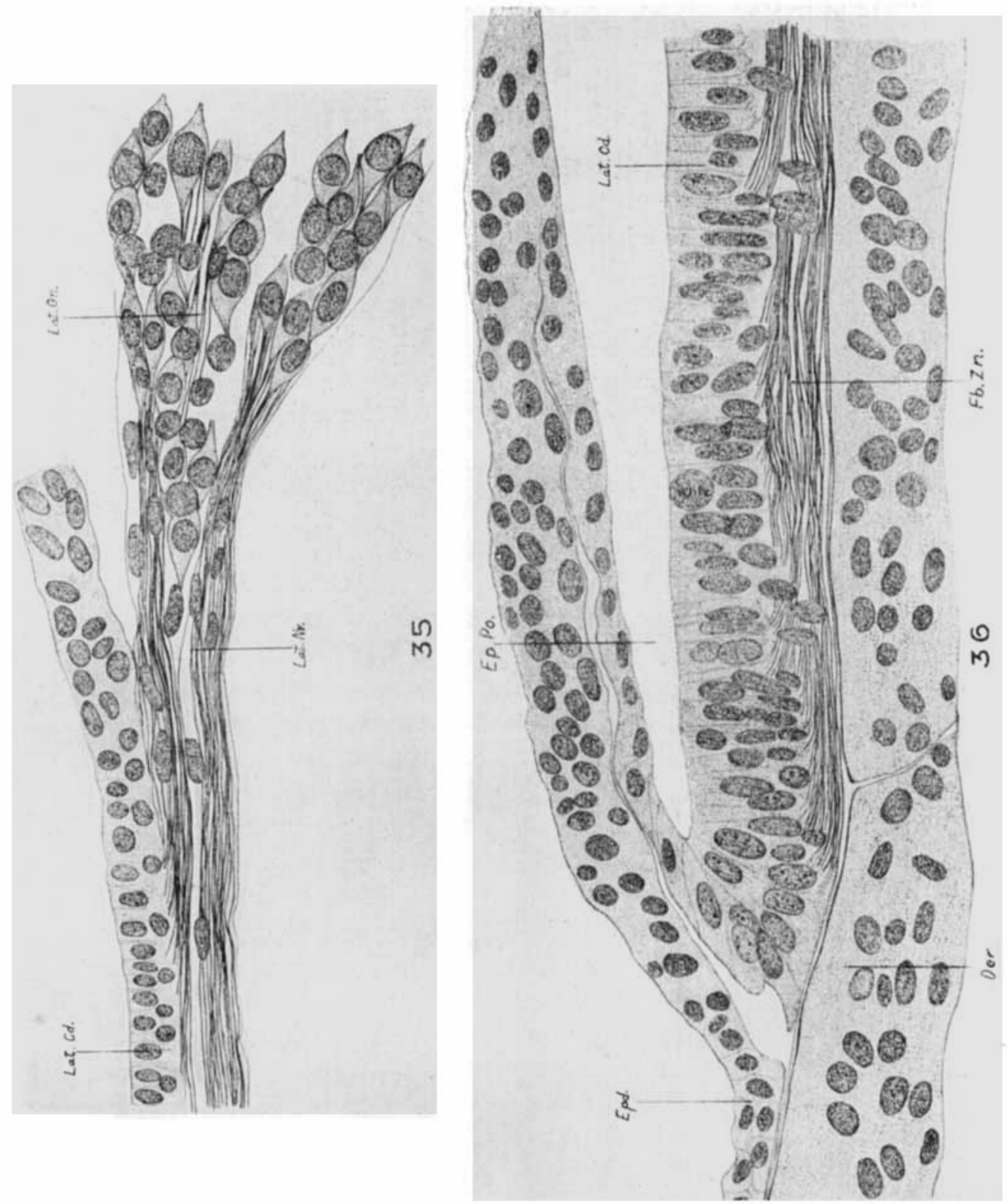
fibers of the ganglion cells pass directly to the inner surface of the ectodermal thickening, where they ramify amongst the cells which are already becoming differentiated to form the sensory column (figs. 35, 36). This primitive lateral nerve lies immediately subjacent to the cells of the sensory epithelium. The grouping of the fibers into ramuli is a secondary process of which there is as yet no indication.

Figure 36 is a longitudinal section of the growing end of the lateral sensory cord, showing the ectodermal pocket, the sensory column and the terminal fibers of the lateral nerve. The nature of the ectodermal pocket is well shown-it is a fold of the outer layer of the skin curving over the thickened growing end of the sensory cord. It takes no part in the formation of the canal which subsequently arises by a process of involution of the sensory epithelium and the closure of the groove thus formed. The overlying epidermal fold, although it becomes much elongated, breaks down and disappears before the true canal is formed.

The epithelium of the growing end is undergoing differentiation. Some of the cells are assuming a columnar or a spindle form, while others appear to be assuming the features of hair cells. Abundant mitotic figures indicate rapid growth of this part of the cord. The continuity of the sensory column is unbroken, there being as yet no differentiation of the cells into the little groups or clusters that a little later are characteristic of the sensory column.

Seventeen millimeter stage. This embryo is slightly in advance of the last stage.

On the head the supraorbital thickening has grown forward to a point above the middle of the eye. Its companion cord, the infraorbital, is about the same length and is directed forwards close to the inferior margin of the eye. Immediately subjacent to the thickened cords of ectoderm, and in close association with the cells of the latter, are large bundles of nerve fibers which arise from the ganglia of the seventh nerve and which accompany the growing cords of thickened ectoderm.

The lateral thickening has assumed more definite form and extends posteriorly to the anterior margin of the pectoral fin- 
bud. It appears as a narrow, slightly elongated cord, and the epidermal infolding at its growing end has assumed the character of a little pouch with its crescent-shaped opening directed forwards. The shape of the fold is explained by the fact that the central part is carried backwards by the rapidly elongating thickened cord of ectoderm, while the upper and lower margins are retarded by the neighboring common ectoderm with which they are continuous.

The root of the lateralis ganglion has become more distinct and its superficial attachment to the brain wall is more widely separated from the vagus roots. From the posterior limit of the ganglion, which is sharply defined, a large bundle of nerve fibers passes to the inner surface of the lateral sensory cord.

Eighteen millimeter stage. In this embryo (fig. 37) all of the sensory cords have greatly elongated. The supraorbital reaches almost to the anterior margin of the eye; the infraorbital has attained an equal growth below the eye, and both cords appear as narrow ridges occupying perceptible grooves. For their greater length the nerves which supply these cords lie immediately subjacent; owing to the growth of the embryo, however, the proximal ends of the nerves now occupy a position slightly beneath the integument.

Ectodermal folds appear at the growing ends of the head cords, but their walls degenerate rapidly and for that reason they do not assume the character of an elongated tunnel such as develops over the lateral cord.

The lateral cord of this stage reaches as far caudad as the middle of the pectoral fin (fig. 37). It shows marked lateral convexity and lies in a slight groove. The epidermal tunnel is rather prominent. This primitive tunnel must not be confused with the lateral canal which arises later.

The growing end of the lateral cord is greatly enlarged with dividing cells and it is quite evident that the superficial ectodermal tunnel is formed by the ordinary ectoderm as it is pushed up by the growing sensory cord. The layer of ectoderm which was originally continuous with the lateral sensory canal anlage is carried along with the growing end, thus giving two layers to the outer wall of the ectodermal tunnel (figs. 38, 36). 

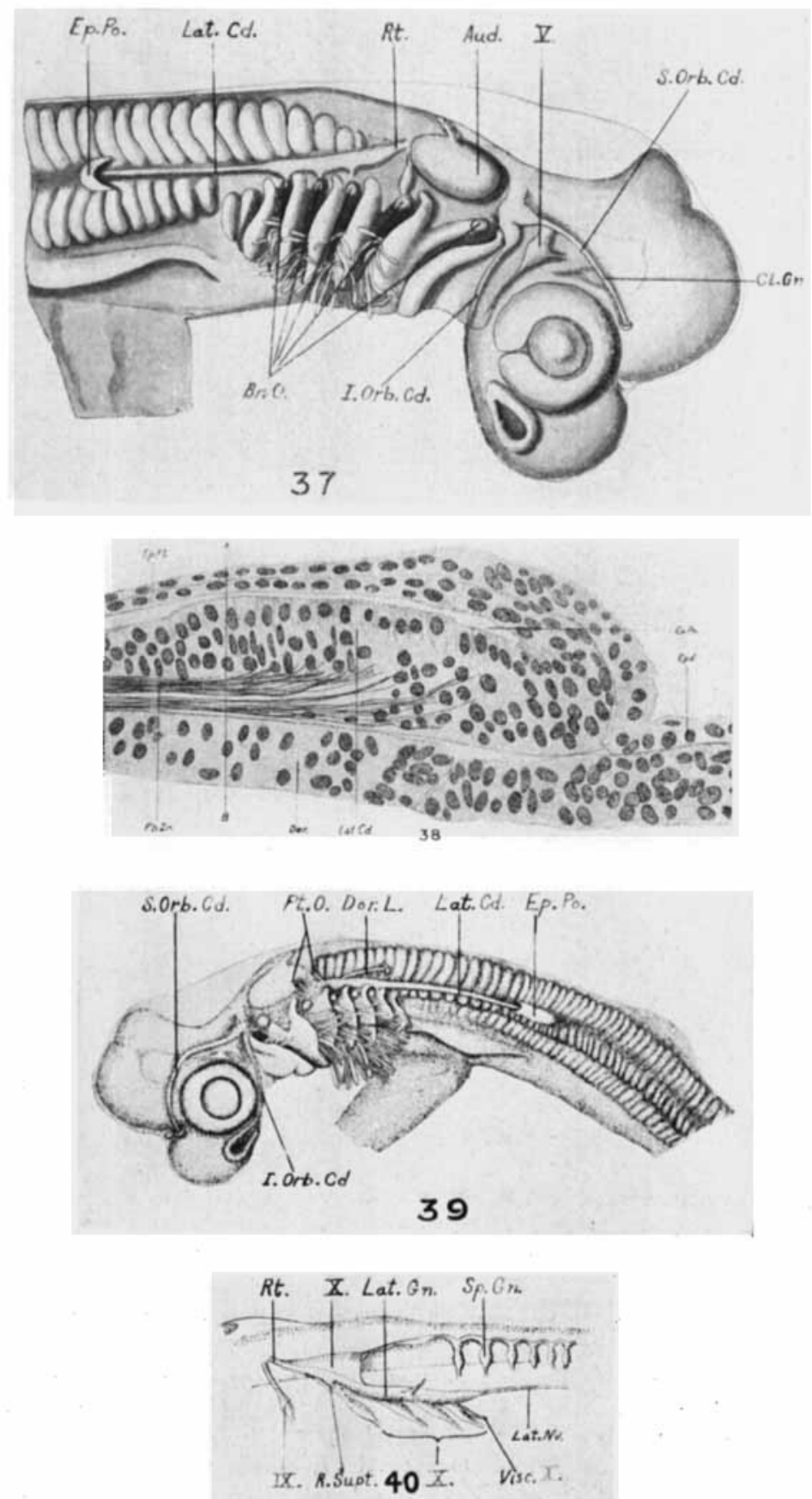
The nerve distribution to the sensory cord is continuous throughout its length. The cells of the cord have not taken on a definite arrangement, although the different types of cells characteristic of the adult appear to be differentiating.

Twenty millimeter stage. In this specimen (fig. 39) is first seen the rudiment of the dorsal series of pit organs. It is a narrow, slightly thickened cord of cells arising as an off-shoot from the suprabranchial ectoderm in a manner entirely comparable to the origin of the lateral and head cords. There is a little ectodermal pocket at its growing end and it carries nerve fibers from a branch of the lateralis ganglion (fig. 40).

The lateralis and vagus ganglia (fig. 40) are somewhat more advanced than in previous stages. The branch that innervates the series of pit organs mentioned above is shown in figure 40 . It springs from about the middle of the lateralis ganglion and extends obliquely upwards and backwards.

As shown in sections the lateral nerve is still in close association with the inner surface of the sensory cord (fig. 41). Farther caudad the lateral nerve is separated into four bundles (fig. 42). Transverse sections (figs. 42,43 ) of the sensory thickening show its relative size and degree of differentiation at different levels. A distinct enlargement is evident at the distal end where the thickening is composed of several layers of cells, many of which show the mitotic figure. Anterior to the epidermal tunnel (fig. 42) the cells of the sensory cord show considerable differentiation and longitudinal invagination of the sensory epithelium appears to have begun.

Fig. 37 Surface view of an $18 \mathrm{~mm}$. embryo. The lateral, supraorbital, and infraorbital sensory cords have greatly extended in length. The branchial sense organs of Beard are also quite prominent. From a sketch by Otto Swezey. $\times 12$.

Fig. 38 Horizontal section of the growing end of the lateral sensory cord. Squalus, $18 \mathrm{~mm}$. See figure 43 .

Fig. 39 Surface view of a $20 \mathrm{~mm}$. embryo. In this specimen the dorsal cord is well defined and the rudiments of two supratemporal pit organs (Pt. O.) have appeared. Squalus. From a sketch by Otto Swezey. $\times 6$.

Fig. 40 Lateral dissection of the medulla of a stage sirnilar to that shown in figure 39. The rami which supply the supratemporal commissure and the dorsal line of pit organs appear as small offshoots from the lateralis ganglion. $\times 13$. 

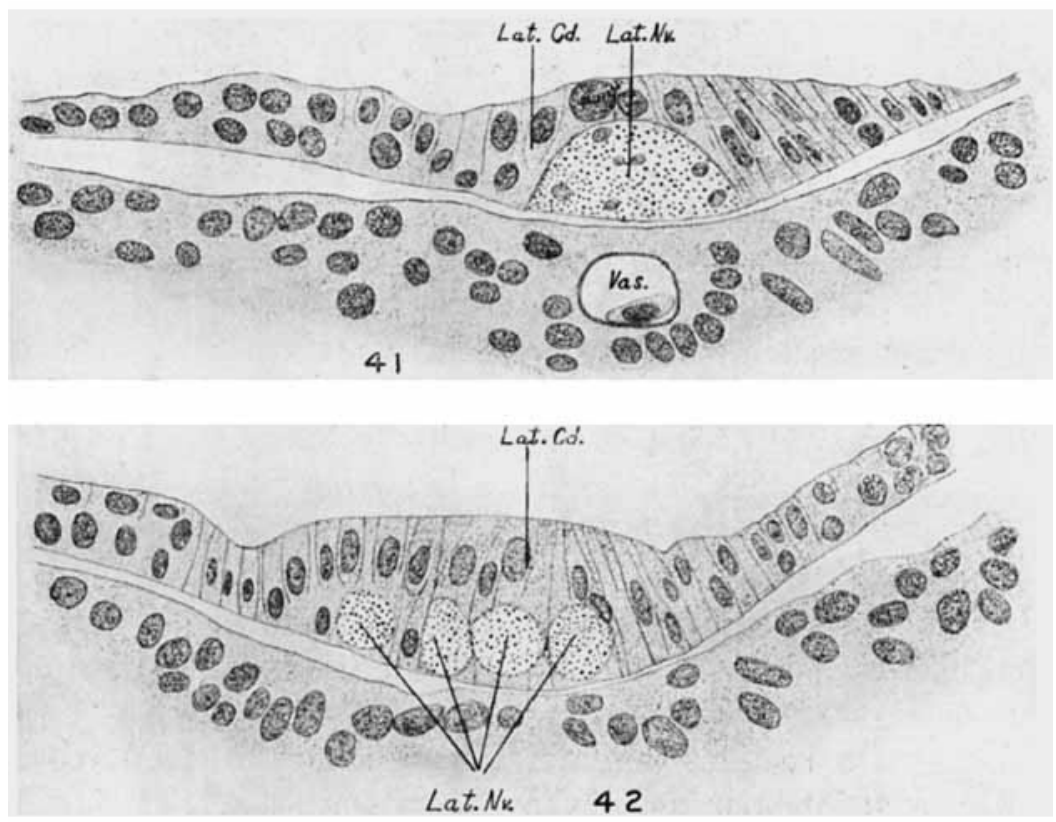

Fig. 41 Transverse section of the lateral sensory cord, of a $19 \mathrm{~mm}$. specimen, near its anterior end. The large lateral nerve has caused a slight bulging of the overlying ectoderm. Squalus. $\times 592$.

Fig. 42 Transverse section of the sensory cord of the same specimen as shown in figure 41 , further caudad. The fibers of the lateral nerve have separated into four bundles. $\times 592$.

Fig. 43 Transverse section of lateral sensory cord at point indicated by the line $A-B$ in figure 38 . Squalus, $20 \mathrm{~mm}$. specimen. $\times 300$.

fFig. 44 Surface view, Squalus $21 \mathrm{~mm}$. From a sketch by Otto Swezey. $\times 8$.

Fig. 45 Dorso-lateral dissection of a similar stage. $\times 12$.

Twenty-one millimeter stage. An embryo $21 \mathrm{~mm}$. long is represented in figure 44 . In it the structures described in previous stages are a little further advanced. Figure 45 shows a partial lateral dissection of an embryo of the same age. The ganglia of the seventh are exposed together with the nerves that pass from them to the supra- and infraorbital lines. The independence of the very elongated lateralis ganglion is clearly exhibited. In this figure should be especially noted the nerve trunk for the dorsal series of pit organs. 

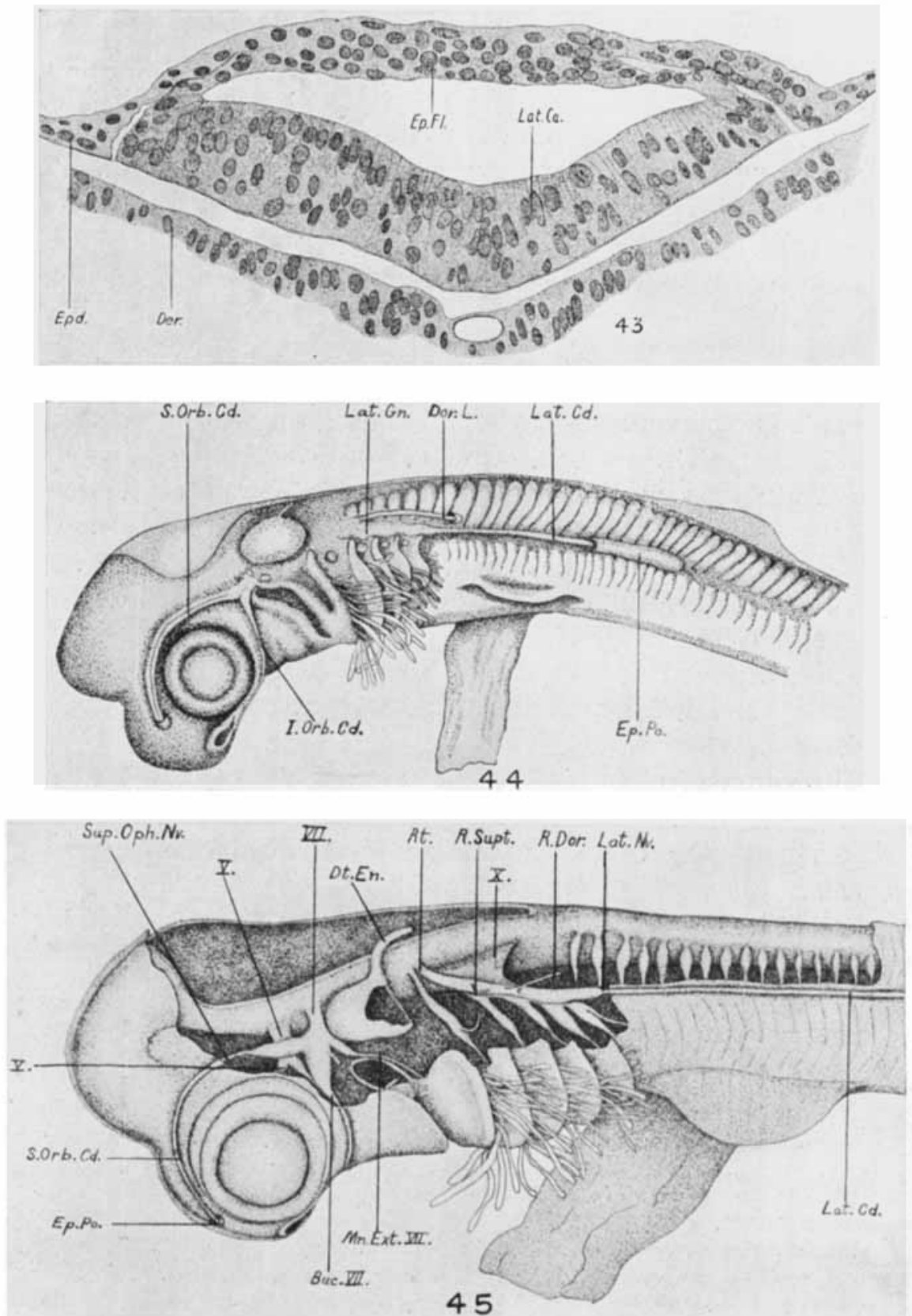
In horizontal section the growing end of the lateral cord of this stage appears practically the same as that shown in figure 36 .

Figure 46 is a cross section in front of the ectodermal pocket near the pectoral fin. The nerve cord is well defined in this situation. It lies close against the sensory cord and produces a slight bulge on the surface.

Twenty-two and one-half millimeter stage. In this stage (fig. 47) it is important to note two little off-shoots of the thickened ectoderm which pass dorsalwards posterior to the ductus endolymphaticus. They take their origin from the suprabranchial ectoderm and ectodermal folds are pushed up at their distal ends. These small cords are substantially similar to the other sensory thickenings. Like the dorsal cord, they undergo subsequent partial degeneration or, at least, great modification. In the adult each of the two small cords is represented by single isolated pit organ, while the dorsal cord is represented by a series of separated pit or surface organs.

The dorsal cord is still short, although it has thickened considerably and has a prominent fold of ectoderm at its distal end.

The supraorbital and infraorbital cords have not only become greatly extended, but they have also begun to invaginate or sink beneath the surface preparatory to the formation of closed canals.

The lateral cord extends as far caudally as the posterior border of the first dorsal fin. The ectodermal tunnel forms a long tube over its growing end, although its anterior lip has also receded to a considerable extent.

Fig. 46 Transverse section of lateral sensory cord at level of pectoral fin. Note the slight bulging caused by the relatively large lateral nerve. Squalus, $21 \mathrm{~mm} . \quad \times 592$.

Fig. 47 Surface view of a $22 \mathrm{~mm}$. embryo. Squalus. From a sketch by Otto Swezey. $\times 625$.

Fig. 48 Dorso-lateral dissection of a $22 \frac{1}{2} \mathrm{~mm}$. specimen showing the nerves concerned in the innervation of the various sensory cords. Squalus. $\times 13$. 

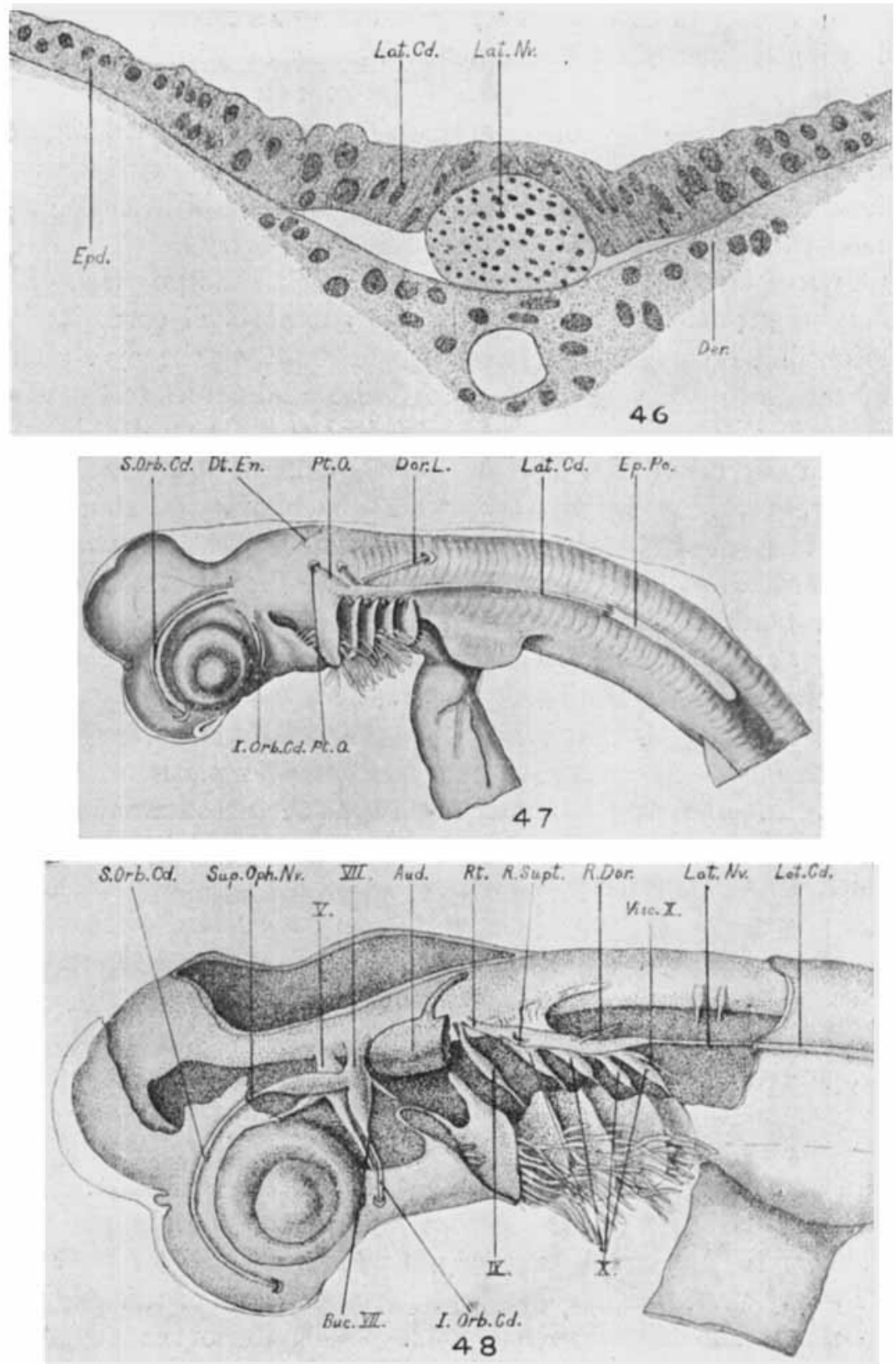

THE JOURNAL OF COMPARATIVE NOUROLOGY, VOL. 28, NO. 
Figure 48 represents a lateral dissection of a $22.5 \mathrm{~mm}$. embryo showing the ganglia and the nerves associated with the sensory cords. Note again in this stage the branch to the dorsal pit organs and the one to pit organs of the supratemporal region. Anteriorly the lateral nerve has now come to lie slightly below the integument, but a little farther back it is still in close contact with the ectoderm (fig. 49).

Twenty-five millimeter stage. In this embryo (fig. 50) marked growth has occurred in the supraorbital cord, its inferior limb now bending backward in front of the eye. The infraorbital is considerably extended also, and passes to the ventral side of the head. The infraorbital and supraorbital both present slight grooves, and at their proximal ends the lips of the grooves have begun to approach each other in short sections or segments. The spaces between the sections with approximated lips become smaller in advanced stages and remain as the pores of the tubules in the adult.

The dorsal cord has pushed back a little farther and has a long epidermal tunnel at its growing end.

The lateral cord now extends to the posterior border of the anal fin and the ectodermal tunnel extends forward to the first dorsal fin. It is to be kept in mind that the ectodermal tunnel is a temporary structure and is not to be confused with the canal which is a later formation.

A perceptible groove has appeared on the surface of the cord anterior to the opening of the ectodermal tunnel and the mouth of the tunnel has receded to the first dorsal fin.

A lateral dissection of a specimen of the same length is shown in figure 51. In front are shown the ganglia from which issue the nerves that supply the supraorbital and the infraorbital lines. Posteriorly is exposed the long lateralis nerve. Two branches are given off from the body of the ganglion. The anterior one goes to the supratemporal commissure and the posterior to the dorsal series of pit organs.

Twenty-seven millimeter stage. Surface views of this embryo are represented by figures 52,53 . The anterior canals have extended to the ventral surface of the head. The supraorbital 

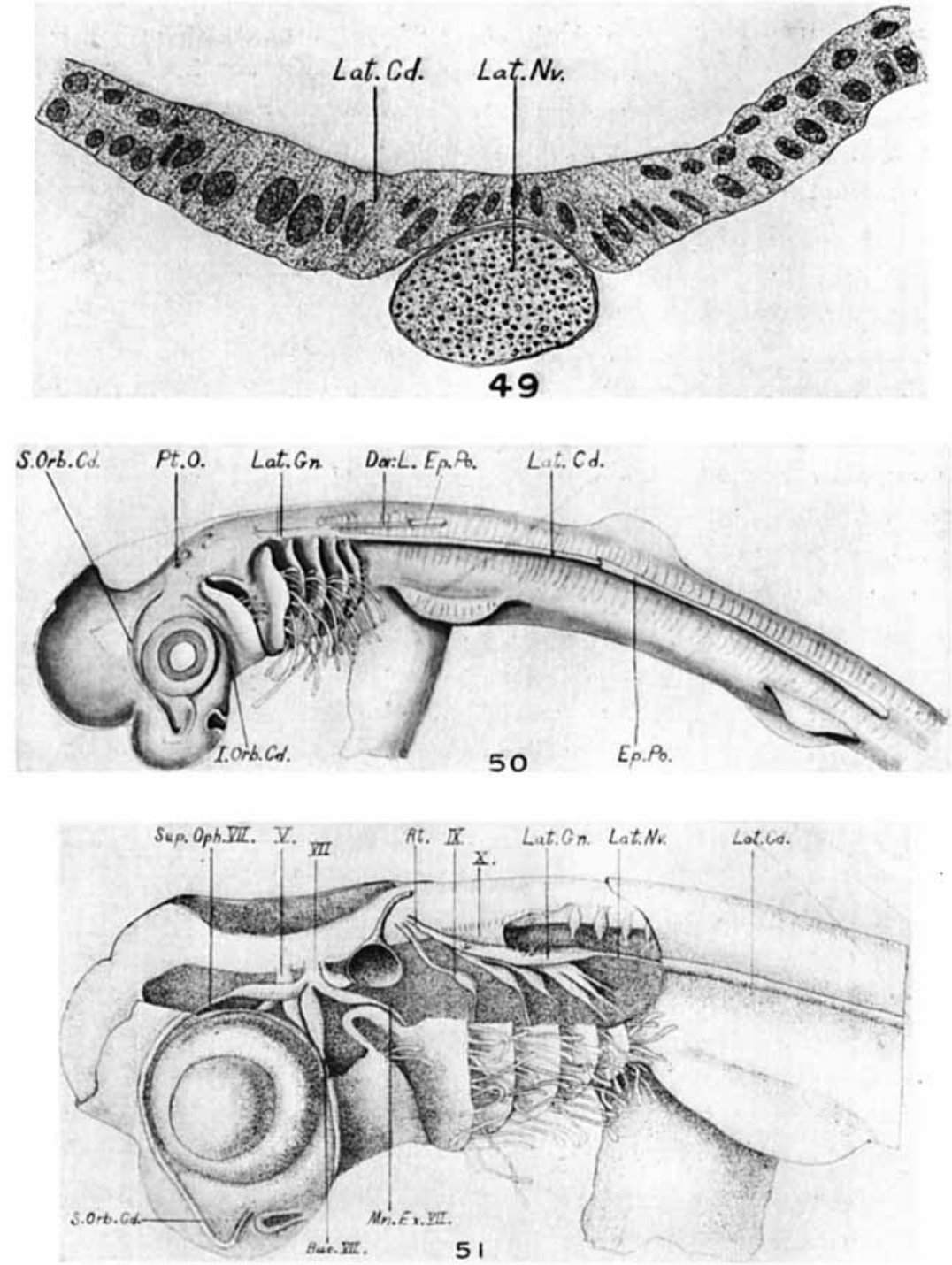

Fig. 49 Transverse section of lateral sensory cord and lateral nerve pectoral region. Squalus $22 \mathrm{~mm}$. $\times 592$.

Fig. 50 Surface view of a $25 \mathrm{~mm}$. Squalus embryo. From a sketch by Otto Swezey. $\times 62$.

Fig. 51 Dorso-lateral dissection of a similar stage. $\times 13$. 
has lengthened and passes backwards between the eye and the nostril, while the infraorbitals draw close to each other in front of the buccal orifice and then bend forward a short distance between the nostrils (fig. 53). The grooves of the head thickenings are now quite deep and at their proximal ends the lips of the canals have begun to fuse or coalesce.

As scen on the ventral surface the hyomandibular sensory cord bifureates at the angle of the mouth (fig. 53), one arm passing forward and the other backward.

The anlage of the supratemporal commissure has made its appearance as a short ectodermal cord passing dorsalwards immediately posterior to the opening of the ductus endolymphaticus (fig. 52). Two little rounded thickenings in front of the ductus endolymphaticus represent the remains of the two short thickenings shown in figure 47 , and mentioned in the description of the $22 \mathrm{~mm}$. embryo.

The lateral cord has extended posteriorly as far as the second dorsal fin, and the dorsal cord almost as far as the first dorsal. A new cord has arisen between the anterior end of the lateral cord and the point of origin of the supraorbital and infraorbital canals, with which it unites some time later.

A dissection of the lateralis ganglion and the adjacent territory is shown in figure 54. Arising from the body of the ganglion are the branches that supply respectively the supratemporal commissure and the dorsal series of pit organs. The lateralis nerve shows an interesting condition. It is divided into two strands. From the upper strand are given off ramuli of nerves that go to the accessory sense organs and from the lower strand similar ramuli whose fibers supply the canal sense organs. Dissections of other specimens make it clear that this division into two strands is not always present. It was observed in another specimen $29 \mathrm{~mm}$. long, but in most of the specimens dissected these strands were combined into a single nerve.

A transverse section of the cord near the anterior end of the epidermal tunnel (fig. 55) shows that the fibers of the lateralis nerve have become gathered into a definite trunk which still lies immediately under the sensory cord. The sensory cord 

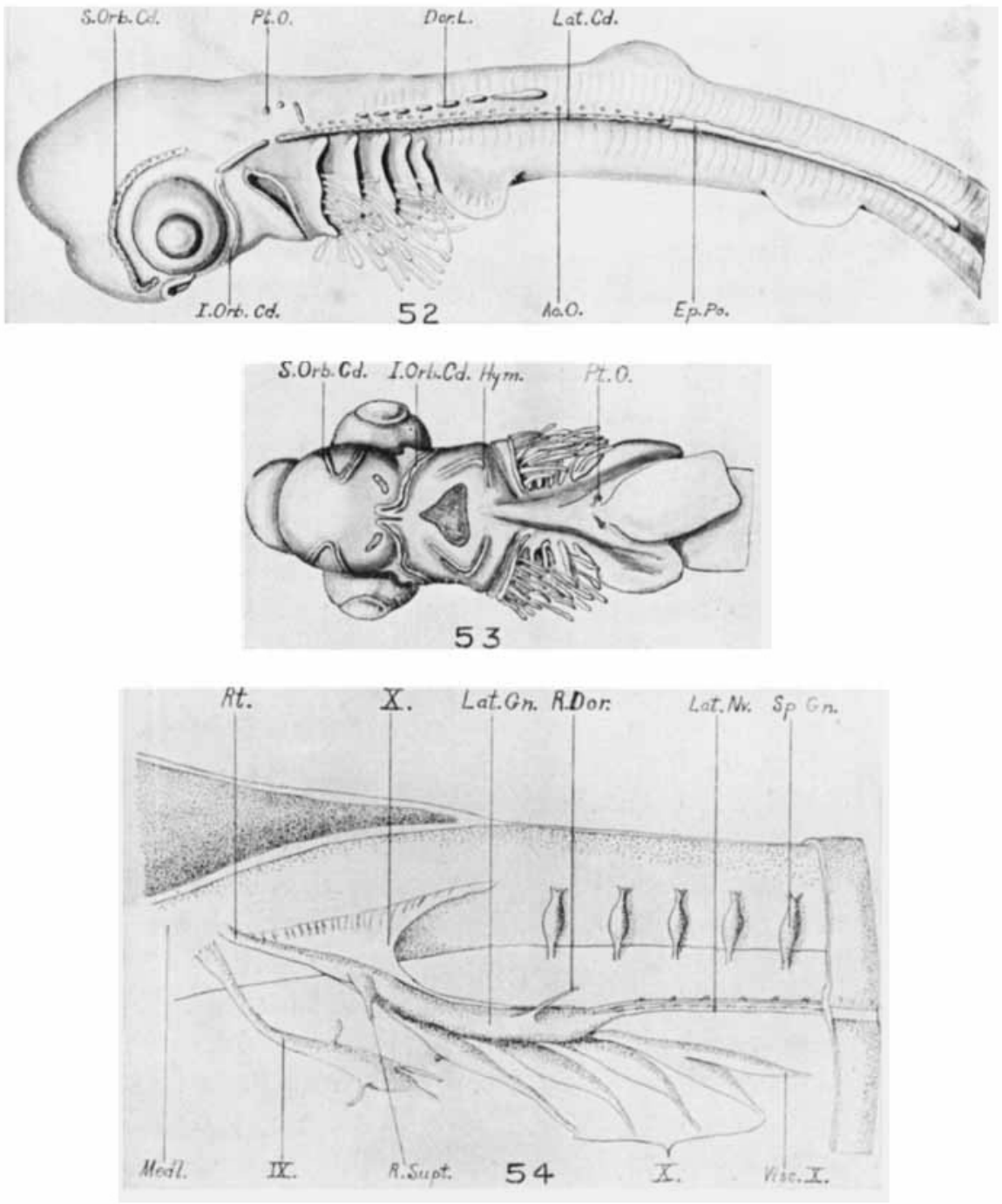

Fig. 52 Surface view of a $27 \mathrm{~mm}$. embryo. Note that the dorsal cord has broken into short scgments and that the accessory organs are now fairly prominent. Squalus. From a sketch by Otto Swezey.

Fig. 53 Ventral view of the same specimen showing distribution of the sensory cords on the under surface of the head. Note the rudiments of two short lines of pit organs (Pt.O.) just anterior to the yolk stalk. Squalus. From a sketch by Otto Swezey.

Fig. 54 Dorso-lateral dissection of the medulla of a stage similar to the one shown in figure 53. Note that the lateral nerve is separated into two main divisions. The upper division supplies the accessory organs. $\times 22$. 
has undergone considerable cellular differentiation so that the main features of the histology of the sense organs are discernible. There are columnar cells, basal cells and sensory cells. The outer wall of the ectodermal tunnel is very thin and shows evidence of degeneration.

Above the lateral sense organ proper is seen in this section an accessory organ which appears to have budded off from the lateral sensory cord and is still within the ectodermal fold (fig. 55). A section anterior to the ectodermal tunnel (fig. 56) exhibits the accessory and the canal organs more widely separated and the lateral nerve considerably removed from the inner surface of the ectoderm.

Accessory sense organs of this kind exist as a longitudinal series running parallel to the lateral sense organs. They are shown in figure 52 just dorsal to the sensory cord. In this specimen they are exposed from the first branchial arch to the dorsal fin and then disappear under the ectodermal fold.

One of the two small sensory cords lying near the yolk-stalk (fig. 53, also fig. 3) is shown in longitudinal section in figure 57. The general resemblance of this section to one of the growing ends of the lateral cord is striking. It has an ectodermal fold and the sensory cord is well provided with nerve fibers. These thickenings are similar to the other sensory cords except that they are more transitory and I was not able to trace their origin from the thickened suprabranchial ectoderm. Of these cords only a few isolated pit or surface organs remain in the adult.

Twenty-nine millimeter stage. In this embryo (fig. 58) the surface changes are not great and consist in the progressive

Fig. 55 Transverse section of the lateral sensory cord posterior to the first dorsal fin. Note that a lateral line organ and an accessory organ are both covered by the superficial epidermal fold. Squalus, $27 \mathrm{~mm}$. $\times 492$.

Fig. 56 Transverse section of the lateral sensory cord farther eephalad (anterior to the epidermal tunnel) than shown in figure 55. Here the lateral nerve lies at a deeper level, and the accessory organ is farther removed from the lateral line organ. Squalus, $27 \mathrm{~mm} . \times 370$.

Fig. 57 Longitudinal vertical section of one of the pit organ rudiments indicated near the yolk stalk in figure 53 (Pt.O.). Squalus, $27 \mathrm{~mm} . \quad \times 492$.

Fig. 58 Surface view of a $28 \mathrm{~mm}$. embryo. Squalus. $\times 3$. 

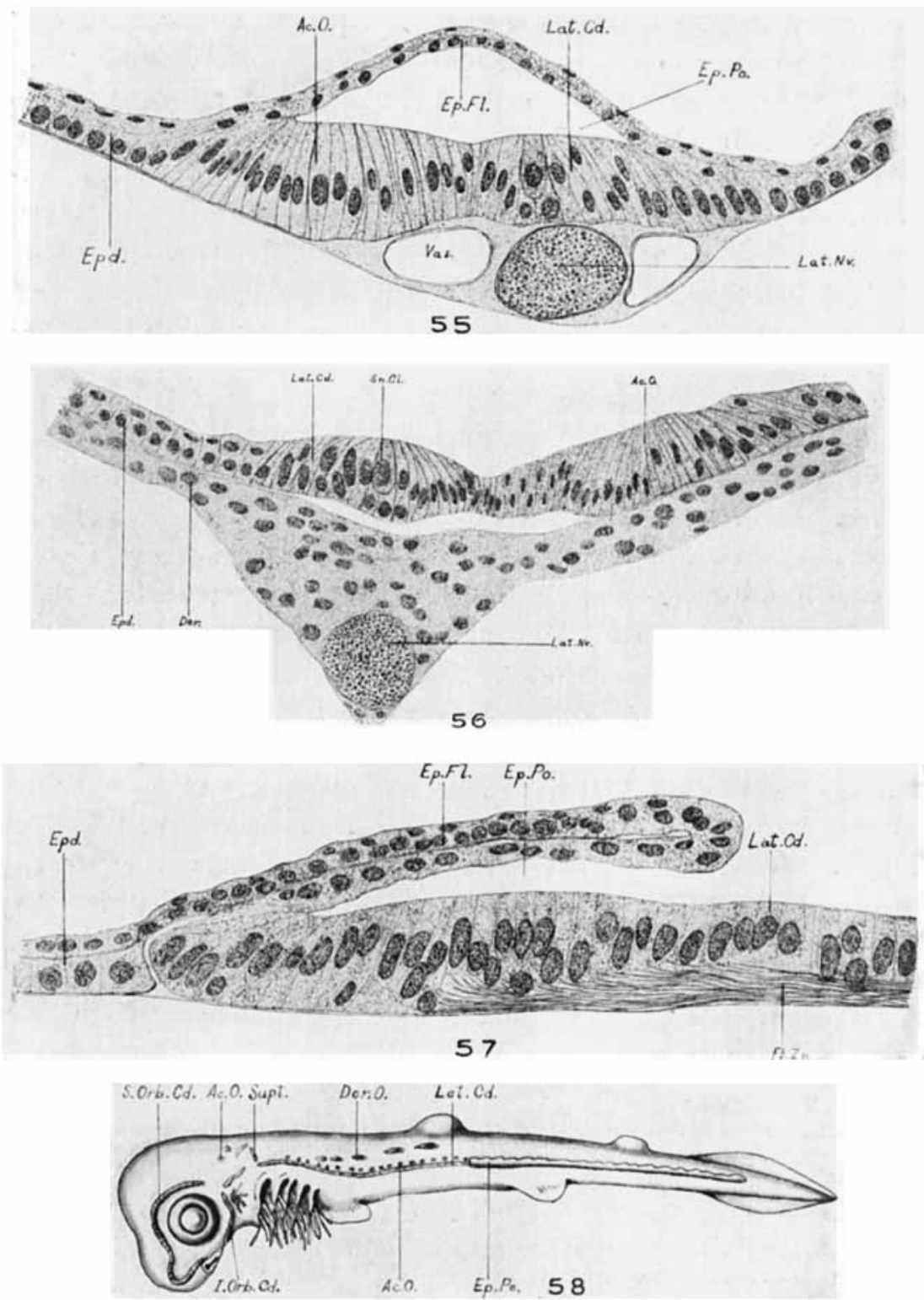
growth of all parts of the lateral line system. The head canals are closed at their proximal ends, and a short cord, sometimes designated the temporal cord, lacks only a little of uniting the lateral and the infraorbital canals.

In the trunk region we can readily distinguish (as also in earlier stages) a dorsal line, an accessory line and a lateral sensory cord.

The growing end of the dorsal cord, extending to the first dorsal fin is still prominent.

The growing end of the dorsal cord is still prominent, although intermediate parts of it have disappeared, leaving a series of separated sensory thickenings which are still enclosed in little epidermal pockets. This is shown in section in figure 59.

That part of the lateral sensory cord in front of the epidermal tunnel now appears as a continuous chain of minute 'swellings.' These swellings are the little clusters into which the hair-cells have grouped themselves and which are characteristic of the adult sensory cpithelium. A longitudinal section of this part of the cord (fig. 60) shows basal cells, columnar cells and sensory cells. As shown in cross section (fig. 62) the sensory column is sunken below the surface but is not as yet enclosed within a canal.

Immediately above the lateral cord is a series of separated 'swellings,' just a little larger than the cell clusters of the lateral cord, and less numerous. These have been termed accessory lateral line organs. Their appearanee in longitudinal section is represented in figure 61 . The origin of these organs has not been traced from their earliest appearance. There appears to be little question, however, but that they arisc from the superior margin of the thickening which gives rise to the organs of the lateral canal. Evidence in favor of this view is seen in figure 63, where the lateral and accessory organs are in close association, both lying within the epidermal tunnel (also fig. 55). As the epidermal fold recedes, the organs become uncovered and may be readily seen in surface studies under low magnification.

Thirty-six millimeter stage. In this embryo the course of the canals is completely mapped out with the exception of the su- 

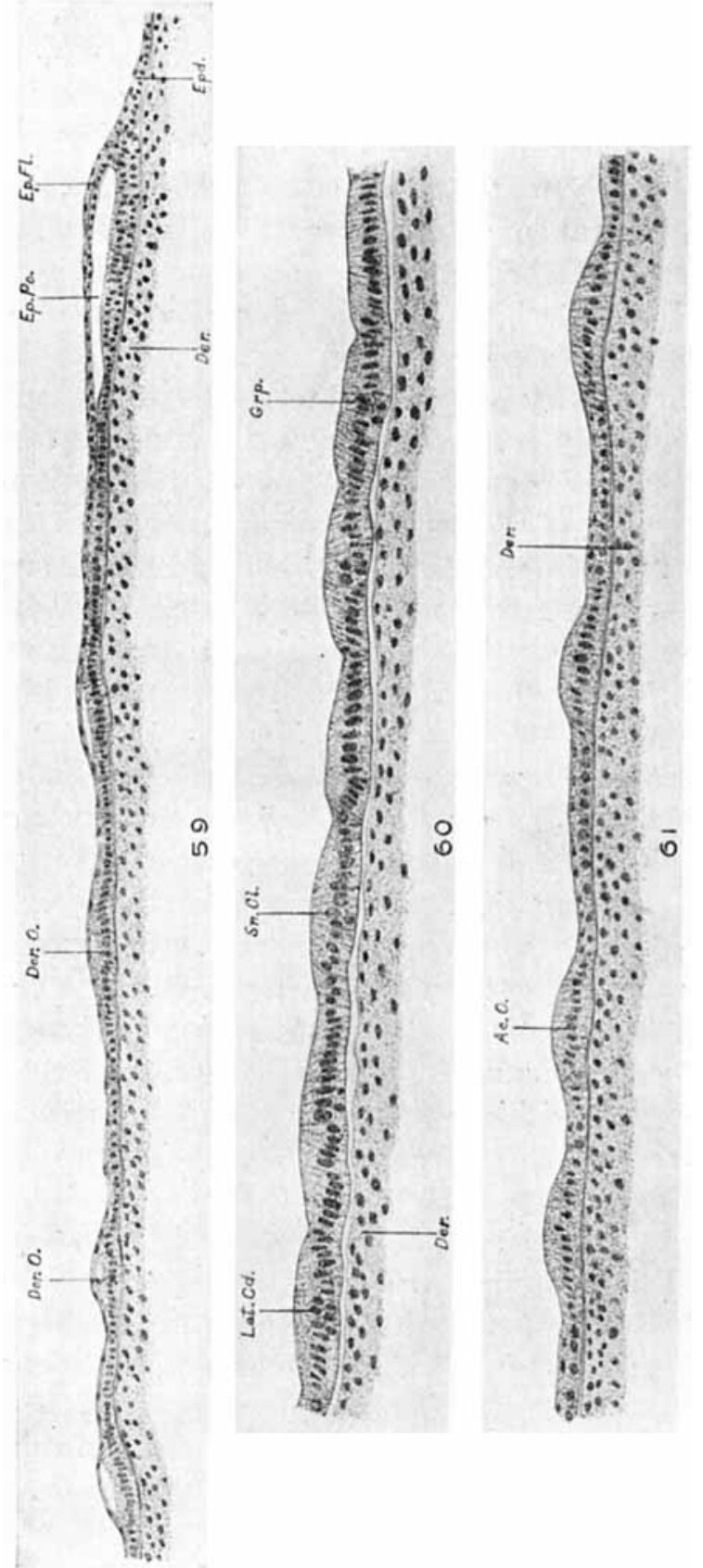

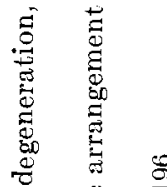

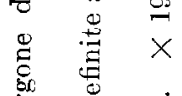

总

㫣帝

焉

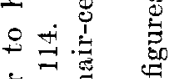

$\vec{x} \bar{x}$

造造总

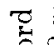

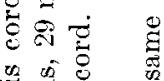

些害苛

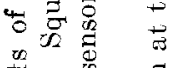

芯范焉

记焉 焉

¿

눙

\%

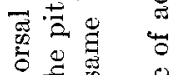

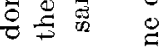

롱

+

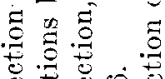

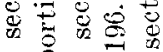

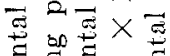

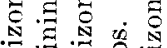

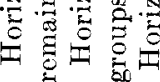

is $\cong 8=\overline{0}$

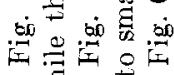

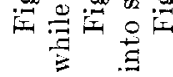


pratemporal commissure, the two arms of which have not yet grown together, and the infraorbitals, which have not yet reached their anterior limit (figs. 64, 65).

The lateral cord has united with the supraorbital and infraorbital canals, anteriorly, and at this stage, which precedes the formation of the lateral canal, it passes to the tip of the caudal fin. The sensory cord presents the appearance of a minute chain of beads lying at the bottom of a shallow furrow. The differentiation of the sense organs is more advanced in the anterior part of the sensory cord than in the posterior part.

The sensory canal system is now practically mapped out and, although great changes occur before it reaches the adult condition, these changes are of a secondary nature, such as changes in relations and closure of the canals. If the system were arrested in its development at this stage, or a little earlier, it would be comparable in a rough way to the lateral sense organs found in certain amphibia, although in the latter the sensory epithelium is much less abundant.

b. Later stages of development-40 to $7 \mathscr{2} \mathrm{mm}$. In the $36 \mathrm{~mm}$. stage it was seen that the distribution of the sensory cords is practically completed, and the nerve connections apparently all established. Cellular differentiation of the sensory cords is also well advanced. Some changes in relations occur and surface tubules become elongated as growth proceeds but the important change which follows is the invagination of the sensory thickenings of the trunk and the gradual enclosure of the main lines of sense organs within epithelial canals. These changes are here described as they appear in embryos of $40,45,52,67$, and $72 \mathrm{~mm}$. in length.

Forty millimeter stage. The head canals which were well on their way towards involution in the $36 \mathrm{~mm}$. stage are now almost completely closed. The pores of the tubules are much smaller than they were and as a result the canals are less conspicuous in surface views.

The groove of the lateral line is closed for a short distance in its anterior region and is represented by a furrow for a consider- 

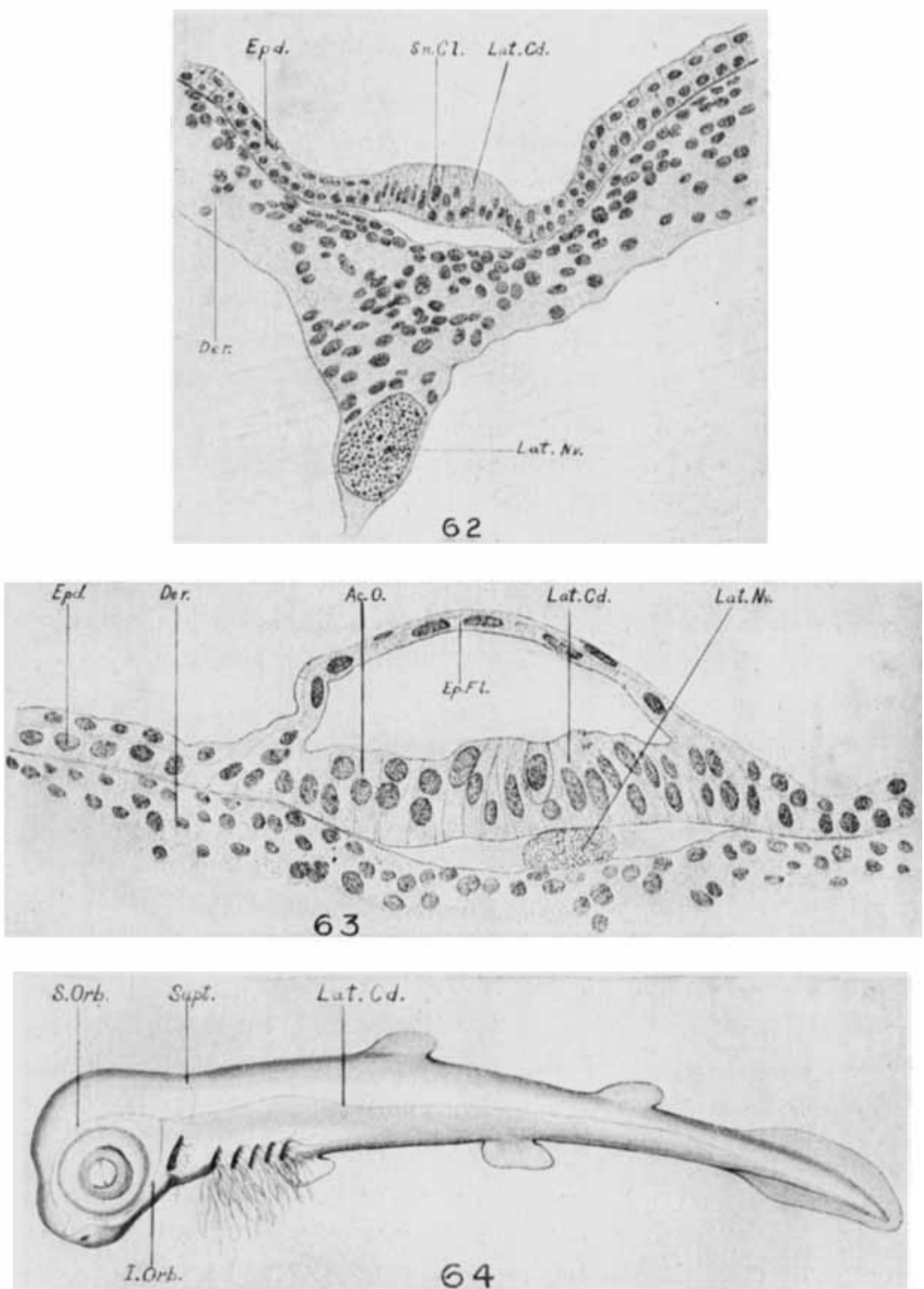

Fig. 62 Transverse section of the sensory cord at the level of the pectoral fin. Squalus, $28 \mathrm{~mm}$. $\times 247$.

Fig. 63 Transverse section, the same specimen, posterior to the second dorsal fin. $\times 492$.

Fig. 64 Surface view of a $36 \mathrm{~mm}$. specimen. Squalus. $\times 24$. 
able distance posteriorly. The $40 \mathrm{~mm}$. specimen was too badly shrunken to afford material for histological study.

Forty-five millimeter stage. In a $45 \mathrm{~mm}$. specimen the trunk canal was closed for a short distance posterior to the pectoral fin. Figure 66 shows a transverse section of the canal anterior to the pectoral fin. Here the canal has just closed and has not yet separated from the epidermis. Figure 67 shows a transverse section a little posterior to the pectoral fin, where the canal lacks only a little of being closed. Considerably farther back the canal is represented by a furrow (fig. 68) which becomes shallower posteriorly. The formation of the canal resembles in its general features the closure of the neural groove to form the neural tube.

Fifty-two millimeter stage. In this specimen the canals of the head are all closed, although the surface openings of the infraorbital are still rather large and somewhat elongated.

The trunk canal as shown in figure 69 is closed nearly to the second dorsal fin. Figure 70 is a cross section of the canal a little farther forward where it has separated from the epidermis. Here the lumen is very small and the condition might easily be mistaken for a solid cord of cells. Posterior to the closed portion it is represented by an open furrow.

The separated organs of the accessory and dorsal scries have reached their permanent number (dorsal series, 11 or 12 ; accessory, about 41) and the former have begun to sink slightly below the surface of the ectoderm. These structures, however, do not become enclosed within canals.

Sixty-seven millimeter stage. In this specimen (figs. 71, 72 ) the canal is tubular for a somewhat greater distance posteriorly. In the region of the first dorsal fin the lumen of the canal has become enlarged and its epithelial walls are relatively thin-

Fig. 65 Ventral view of the same specimen as represented by figure 61, showing distribution of sensory canals on the inferior surface of the head.

Figs. 66, 67, 68 Transverse sections of the lateral canal and cord at different levels of the body. Figure 66, anterior to the pectoral fin; figure 67, posterior to pectoral fin; and 68, posterior to second dorsal fin. All three figures from a $45 \mathrm{~mm}$. specimen. Squalus. $\times 492$. 

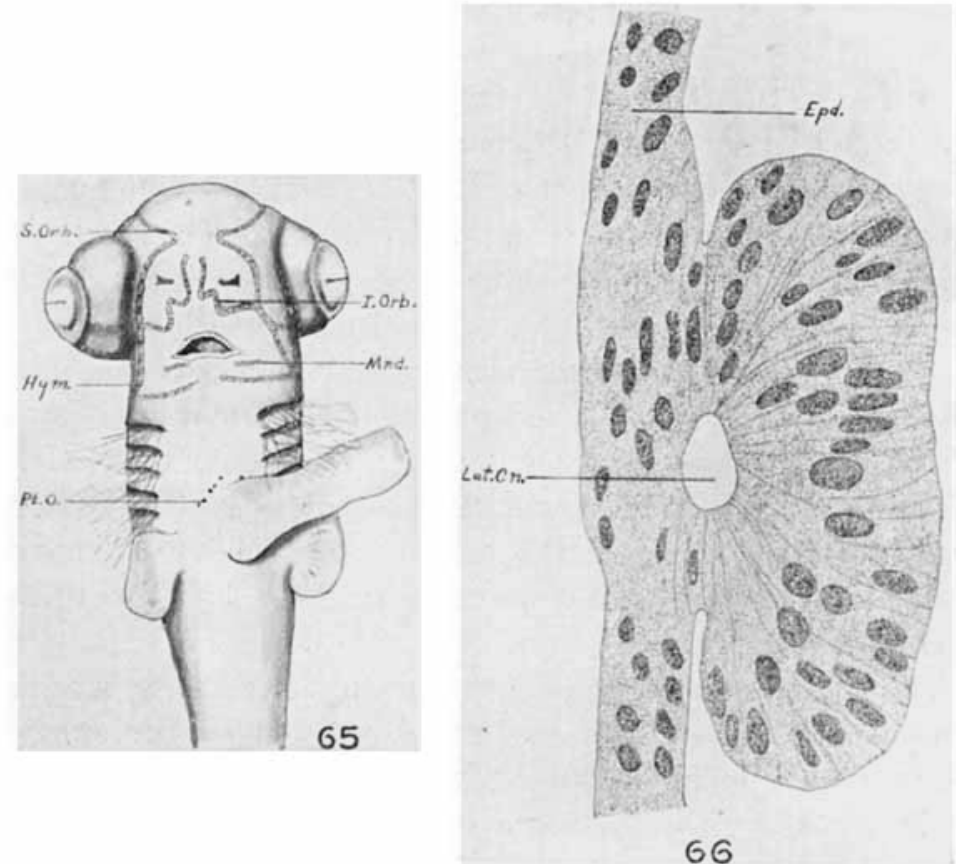

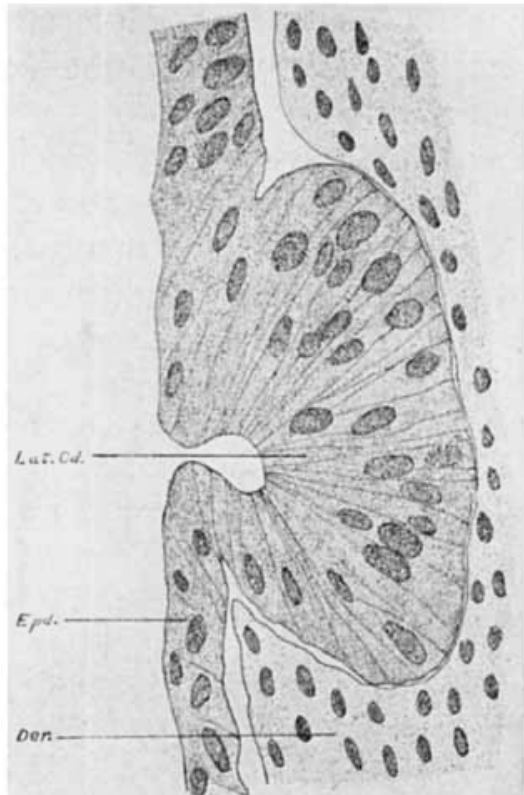

67

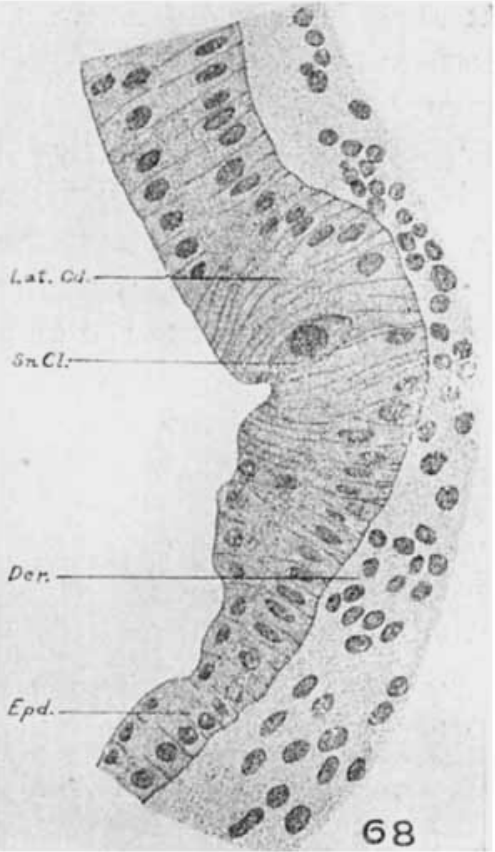


ner (fig. 73). Figures 74 and 75 show transverse sections of the canal somewhat farther back. In figure 74 the trunk canal is almost closed and in figure 75 it is still a wide open groove. Figure 75 shows also an accessory organ which is now considerably removed from the canal and is covered by a superficial layer of ectoderm.

Seventy-two millimeter stage. In this embryo (fig. 76) the canals appeared to be completely closed and could be traced only by the openings of the tubules. Anterior to the first dorsal fin the lateral canal lies considerably beneath the epidermis, its lumen is greatly enlarged, and its epithelial walls relatively thinner than in previous stages (fig. 77). Posteriorly the canal has not yet separated from the epidermis (fig. 78), the lumen is smaller, and here, as in other sections (e.g., fig. 79) it is seen that the columnar layer of the canal wall is continuous with the columnar layer of the epidermis.

In surface view the various lines of true canal organs are represented by continuous lines, the pores of the tubules being too small for representation on the scale of the drawing. The accessory line organs, those of the dorsal line series and those in front of the supratemporal commissure, are represented somewhat larger than their ratio to the outline of the embryo.

The $72 \mathrm{~mm}$. specimen was the most advanced of the embryos at my disposal and therefore it completes my study of the method of formation of the sensory canals. The developmental processes are complete in all essential features, however, as may be seen by a comparison with the conditions found in the adult.

\section{Structure of the sensory canals of the adult}

Distribution. Particular attention has not been given in my observations to the distribution of the various sensory canals in Squalus, although on rather superficial examination enough differences have been noted to enable one to distinguish the two genera by this character alone (Garman '88). In Squalus the lateral eanal lacks the short upward bend at the level of the second dorsal fin which is characteristic in Mustelus. The 

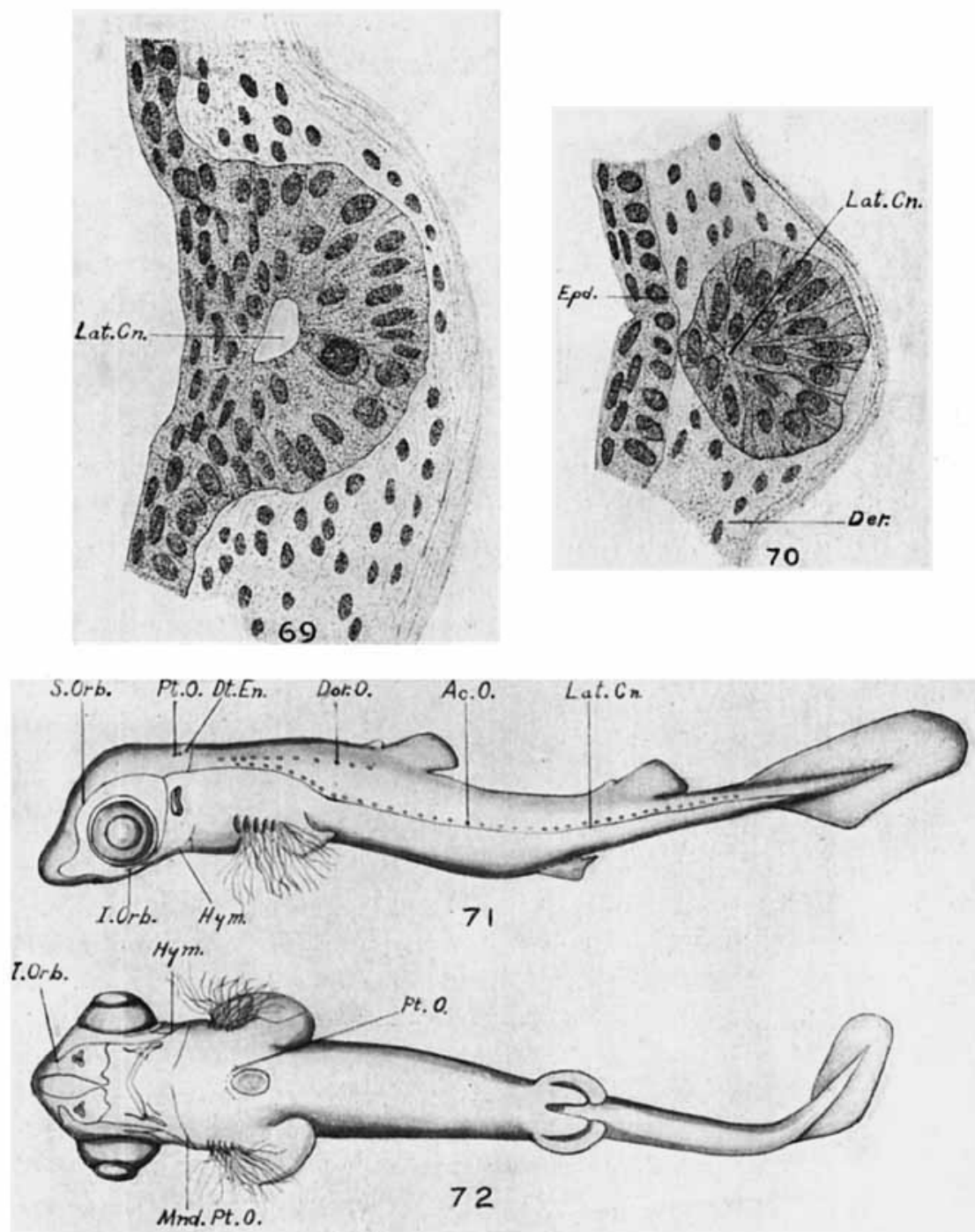

Figs. 69, 70 Transverse sections of the latcral canal at different levels show. ing a great difference in the size of the lumen. Squalus, $52 \mathrm{~mm} . \times 560$.

Figs. 71,72 Lateral and ventral views of a $67 \mathrm{~mm}$. specimen. Squalus. $\times 1 \frac{1}{2}$. 

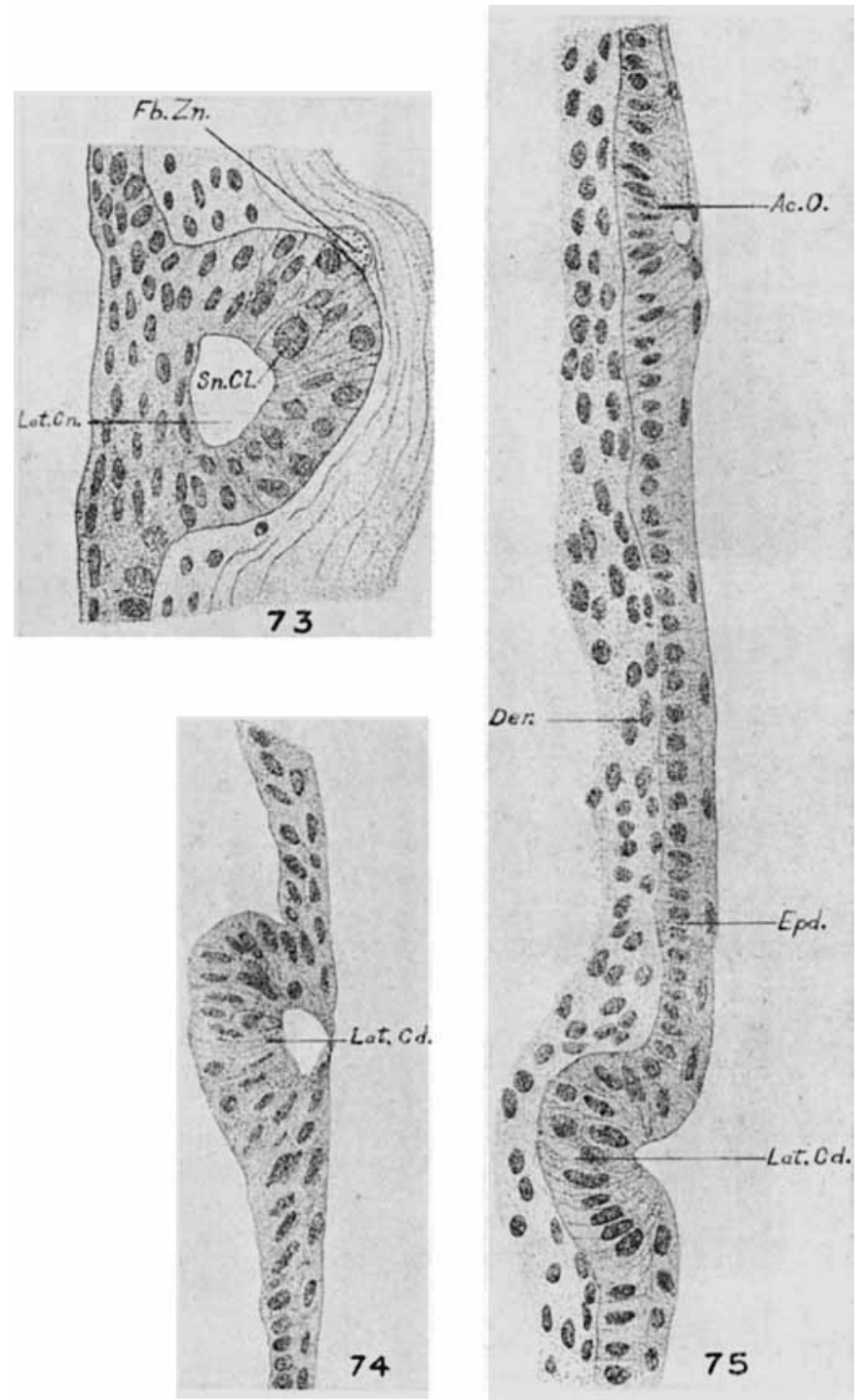

Figs. $73,74,75$ Transverse sections at different levels, showing the lateral canal closed, almost closed, and wide open. An accessory organ is also shown in figure 75 . Squalus, $67 \mathrm{~mm}$. Figure $73, \times 360$; figures 7 and $75, \times 296$. 
infraorbital canals do not appear to anastomose with the supraorbitals as they do in Mustelus, and there are other differences in the supraorbitals and hyomandibulars which I have not examined with sufficient care to describe in detail.
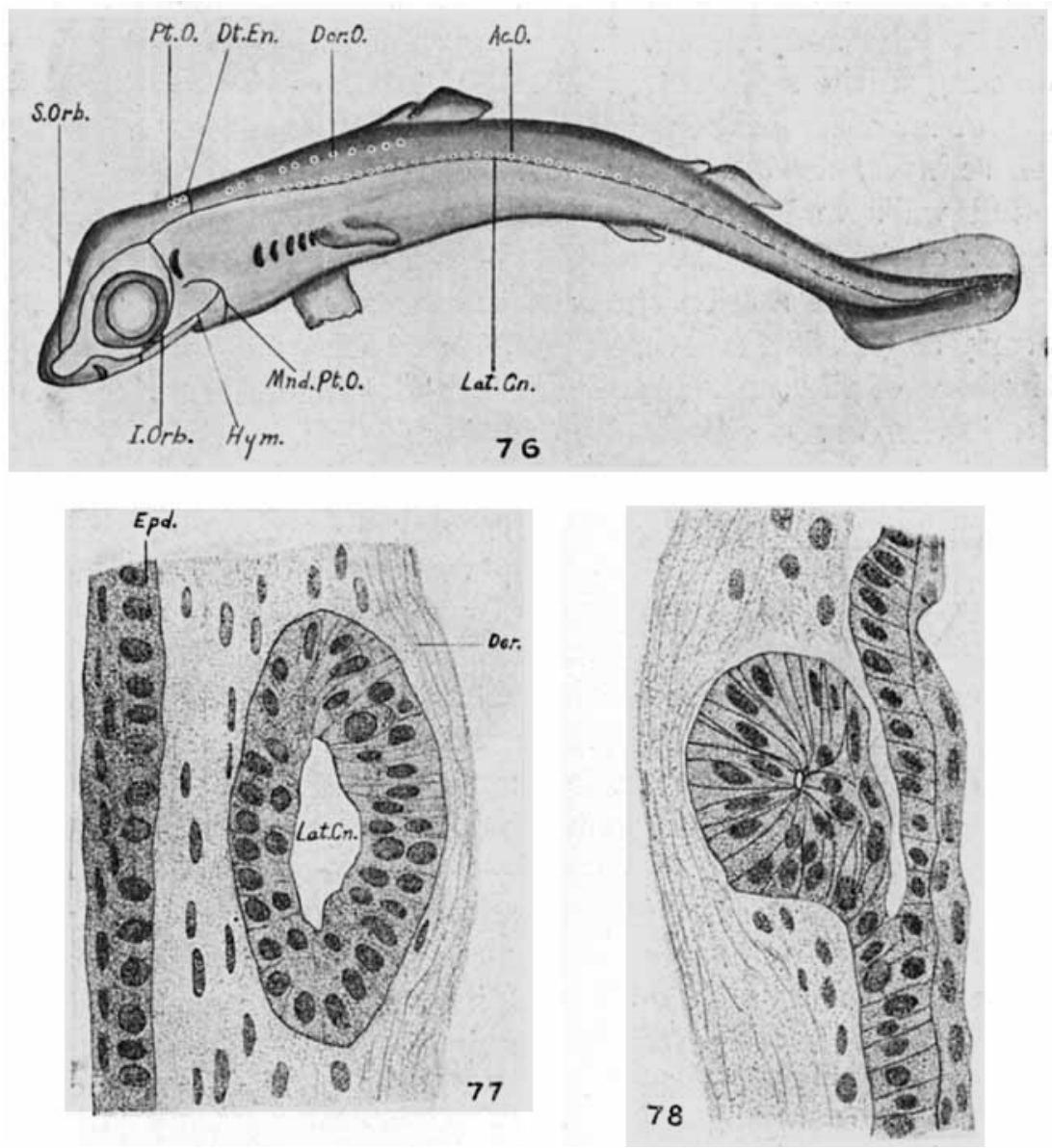

Fig. 76 Surface view of $72 \mathrm{~mm}$. embryo. Squalus. $\times 1 \frac{3}{5}$.

Fig. 77 Transverse section of lateral canal, anterior region of body. Squalus, $72 \mathrm{~mm} . \times 360$.

Fig. 78 A section similar to figure 77 , but farther caudad. Note the small lumen, and also that the canal wall is still attached to the ectoderm. Squalus. $\times 360$. 
Structure. Differences of considerable extent are found in the form of the canals and in the histological structure of the sensory epithelium.

The lateral canals lie in the deeper layers of the dermis and their tubules pass ventralwards for a considerable distance ( 0.1 to $0.5 \mathrm{~mm}$. or more, depending upon their position) before opening to the surface (fig. 80). The walls of the tubules consist of an outer columnar and an inner flattened layer of cells. These layers are continuous centrally with similar layers of the canal walls and externally with the columnar and stratified layers of the epidermis.

In transverse section the sensory canals are usually round or nearly so (fig. 82), and a small bundle of nerve fibers runs along the base of the sensory column (fig. 81). The sensory column lies in the dorso-medial wall of the canal (figs. 79, 80).

The structure of the sensory column is indicated in figures 81, 82, 83. The hair-cells are arranged in small groups (about 3 to 5) around which the supporting elements tend to group themselves in small concentric clusters. Usually only one hair-cell can be seen in transverse sections. The cells are relatively large and each appears to bear a single hair-like process (figs. 82, 83). The supporting elements consist of columnar cells, basal cells, and spindle-shaped cells. These are similar to the corresponding elements found in the sensory column of Mustelus.

Efforts to secure silver impregnation of the peripheral terminations of the lateral nerve of Squalus acanthias were not satisfactory. Fresh Squalus material has not been available and the fixation of the preserved specimens was not suitable for silver impregnation methods. By other methods (iron haematoxylin and Weigert-Pal), however, the lateral nerve has been traced from its central ganglion to the basilar membrane of the sensory column and it appears safe to assume that the terminations are essentially similar to those of the lateral nerve in Mustelus.

The question of the mode of growth of the lateral nerve should be considered. Regarding the growth of the lateral nerve, 

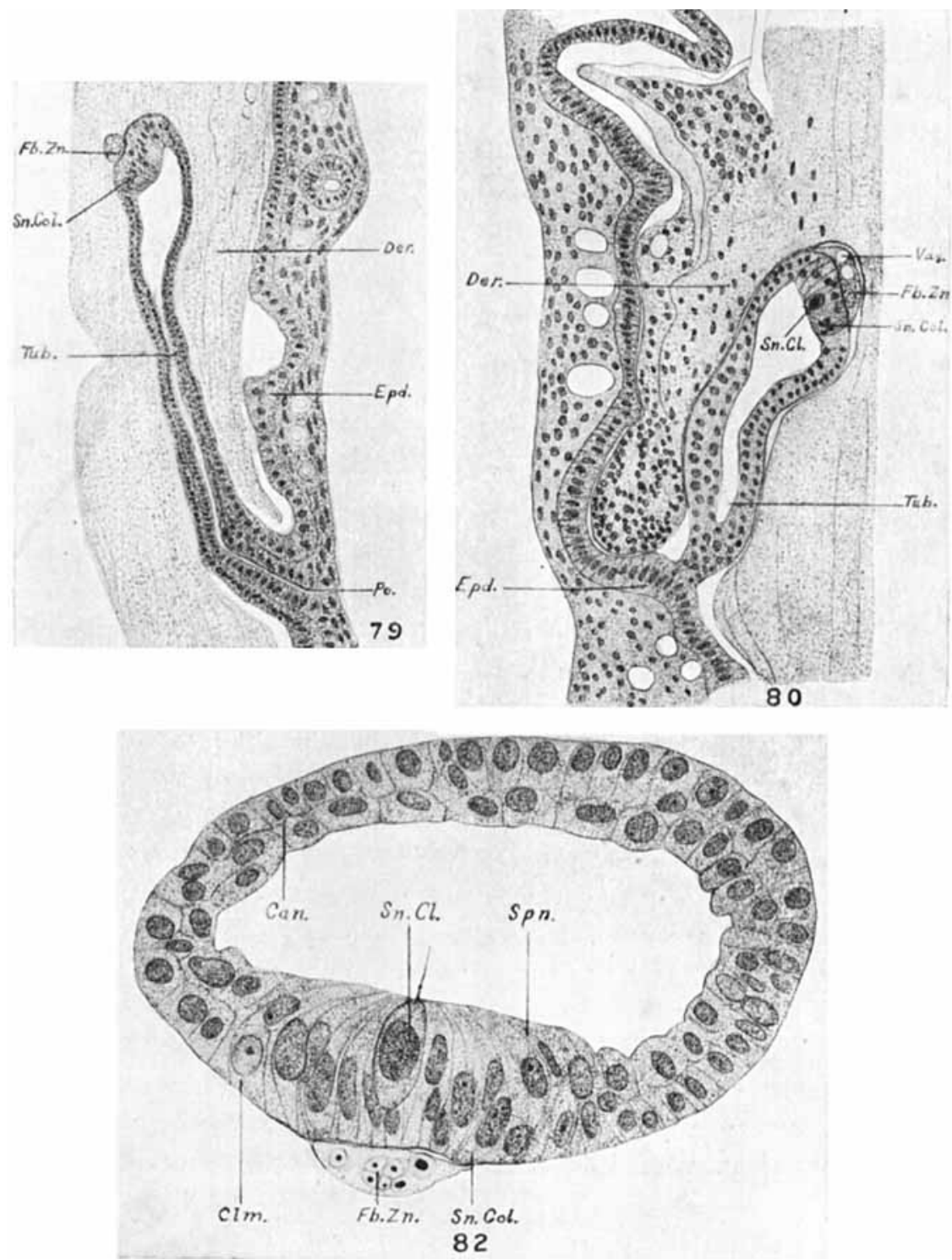

Fig. 79 Transverse section of the lateral canal of a Squalus acanthias (garter stage) showing relations of fiber zone, sensory column, surface tubule, dermis and epidermis. $\times 120$.

Fig. 80 Transverse section of the lateral canal just anterior to the caudal fin. Squalus pup. $\times 136$.

Fig. 82 Transverse section of the lateral canal of a Squalus pup. $\times 592$. 

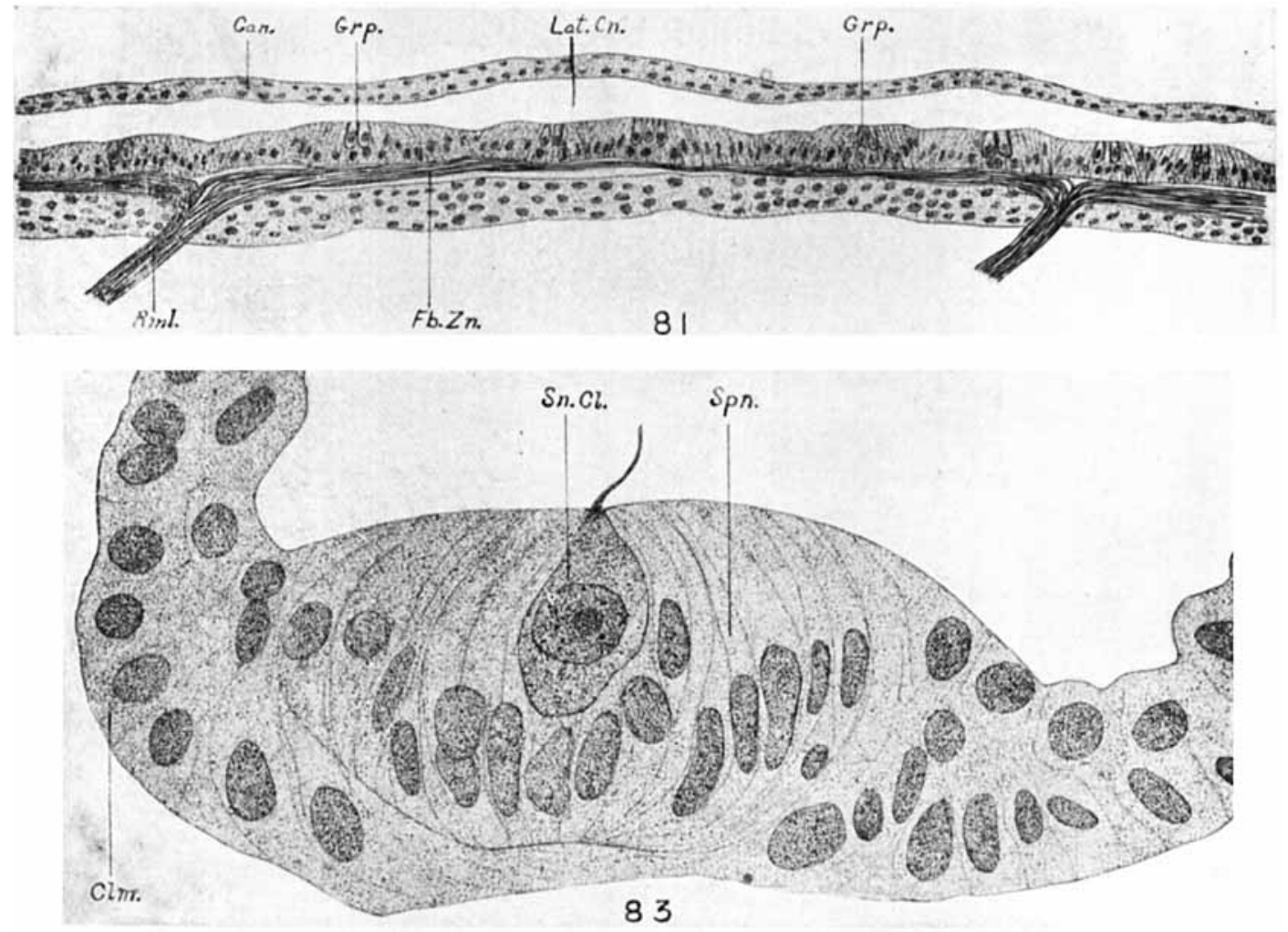

lig. 81 Longitudinal section of the lateral canal of a Squalus pup, showing two lateral ramuli, fiber zone, and sensory epithelium. $\times 136$.

Fig. 83 Transverse section of lateral sensory column of the same specimen (fig. 82). $\times 1160$.

observations on both Mustelus and Squalus show that the nerve fibers grow from the ganglion cells. There is no evidence of addition to the nerve from cells of the integument. The latter are developed into secondary sense cells (Harrison '03).

\section{SUMMARY, CONCLUSIONS AND COMPARISON OF THF FORMS STUDIED}

The sensory canal system embraces two sets of organs designated canal organs and surface or pit organs respectively. As the terms imply, the former are enclosed within epithelial canals and the latter lie at the surface of the skin or in shallow pits. 
The principal canals are the supraorbital, the infraorbital, and the lateral. Two shorter ones are the mandibular and hyomandibular canals. The lateral canals are connected by a short canal, the supratemporal commissure. Only slight differences exist in the distribution of the canals in Squalus and Mustelus.

Four lines of pit-organs have been found in Mustelus and five in Squalus. The dorsal series is the most extensive, in Mustelus, extending from the supratemporal region to the caudal extremity of the body. In Squalus this series extends only to the region of the first dorsal fin. In both Squalus and Mustelus two small pit organs are located immediately in front of the pores of the endolymphatic ducts. Their method of development gives evidence of their relationship to the canal system. Two short lines of organs have been found just in front of the scar left by the yolk-stalk in Mustelus pups and in Squalus embryos up to $72 \mathrm{~mm}$. They have not been found in the adult of either species. Another series of organs common to both forms extends from the lower margin of the spiracle ventralwards around the angle of the mouth and almost to the midventral line. The fifth series of sense organs included in this group is the 'accessory line.' These organs are not strictly homologous to the other organs of the group as they do not have an.independent development, but appear to arise from the superior margin of the lateral sensory cord. Accessory organs have not been found in Mustelus but it is my opinion that their presence could be demonstrated, especially in early embryos.

In structure the sensory canals are epithelial tubes, one wall (usually the superior) of which is specialized to form the sensory epithelium. The canals lie superficially within the dermis or somewhat deeper (on the head) and numerous minute tubules lead from the canals to the surface, passing in a ventro-lateral direction, thus permitting considerable elongation of the tubules, especially in the anterior region of the body. In adult Squalus and Mustelus the tubules of the lateral canal outnumber the vertebrae in the ratio of approximately four to three. 
In both Squalus and Mustelus the sensory epithelium constitutes a continuous column of cells along the superior or supero-medial wall of the sensory canals. In the sensory ridge, however, the hair-cells (sense end-organs) are arranged in little groups or clusters which are separated and surrounded by the supporting cells.

In Squalus the sensory epithelium is less extensive than it is in Mustelus. There are approximately three to five hair-cells in each group and about eight groups between adjacent tubules and ramuli of the lateral nerve. In Mustelus there are several times as many hair-cells in each group and approximately twice as many groups.

In Squalus the sensory canals are somewhat smaller in diameter, they are more nearly round in transverse section, and the sensory epithelium does not occupy as wide a part of the canal wall as it does in Mustelus. The peculiar cells found at each side of the sensory ridge in Mustelus have not been observed in Squalus, nor do the blood capillaries occupy as prominent a position in the latter.

The nerve supply of the sensory canals is practically the same in the two forms considered. The innervation of the lateral canal, which has received more careful attention than that of the other canals, is by a large cranial nerve, the $\mathrm{N}$. lateralis. This is unique among the cranial nerves, extending from the medulla to the caudal extremity of the body.

The cells of origin of the lateral nerve are located in a greatly elongated central ganglion which is partly enclosed in a common sheath with the vagus roots and ganglia, but is, however, independent. From this ganglion the nerve passes posteriorly between the muscles of the lateral body-wall at a considerable depth from the surface. At intervals corresponding to the surface tubules bundles of fibers (ramuli) pass to the base of the sensory column and then branch forward and backward, forming a continuous longitudinal fiber zone from which distribution to the sensory epithelium takes place.

In Mustelus it has been shown that the peripheral terminations of the lateral nerve are in the nature of free ramifications 
between the hair-cells. Owing to the lack of fresh material the peripheral terminations of the lateral nerve in Squalus have not been demonstrated, although the nerve fibers have been readily followed as far as the basilar membrane of the sensory column, and are similar in arrangement to those of Mustelus.

The sensory canals begin their development as linear extensions from certain thickened patches of ectoderm. Two of these thickenings, the suprabranchial and the preauditory are well defined. The points of origin of the mandibular surface organs, and the surface organs which appear in front of the yolk-stalk are not so evident.

By linear extensions the suprabranchial thickening gives rise to the lateral sensory cord, the dorsal series at pit organs, the supratemporal commissure, and two isolated pit organs in front of the pores of the endolymphatic ducts.

Similarly the preauditory thickening gives rise to the supraorbital, infraorbital and hyomandibular sensory cords.

As the sensory cords elongate in their respective directions the ectoderm which lies in their path is pushed up to form little pockets or even long tunnels over the growing ends of the cords. These tunnels are not the canals.

Early in their development cellular differentiation begins in the sensory cords and by the time the thickenings have practically reached their full linear extension they begin to sink into a groove at their proximal ends. As the infolding continues the sensory cords are gradually enclosed within epithelial canals which, however, retain communication with the exterior by means of numerous delicate tubules.

By the time the suprabranchial thickening has become fairly prominent and considerably before the lateral sensory cord has definitely appeared, the suprabranchial ectoderm is separated from the wall of the medulla by a mass of cells, the neuroblasts of which give rise to the lateralis and vagus ganglia. No evidence has been seen to indicate that any of the cells in the ganglionic mass are derived from the external ectoderm. This point, however, has not been the subject of special examination. While the external ectoderm is still in contact with the ganglionic 
mass fibers grow out from the cells of the latter and become associated with the overlying ectodermal cells. Very early in development a longitudinal mass of the ganglionic cells becomes partly separated from the rest. This is the embryonic lateralis ganglion. Its central fibers form a definite root which enters the medulla anterior to, and slightly above, the roots of the remainder of the ganglionic (vagus) mass. Peripheral fibers of the lateralis ganglion have already become associated with the ectodermal cells which proliferate and extend backward as the lateral sensory cord. The fibers which accompany the sensory cord constitute the lateralis nerve. In early embryos the nerve lies immediately subjacent to the sensory cord, but as growth proceeds it recedes from the surface and comes to occupy a position at a considerable depth medial to the ectoderm. As the nerve becomes farther removed from the inner surface of the ectoderm the fibers, which have become associated with the sensory cord, do not pass to the latter in a continuous sheet, but arrange themselves into small bundles, the lateral ramuli.

Mode of formation of the canals. By the time the nerve connections are established as outlined above the canals are closed and the sensory canal system has practically reached the adult condition.

\section{BIBLIOGRAPHY}

AlLIs, E. P. 1888 The anatomy and development of the lateral line system in Amia calva. Jour. Morph., vol. 2.

1902 The lateral sensory canals, the eye-muscles and the peripheral distribution of certain cranial nerves of Mustelus canis. Q. J. M. S., vol. 45.

BALFour, F. M. 1878 The development of elasmobranch fishes.

BeArd, JoHn 1884 On the segmental sense-organs of the lateral line and the morphology of the vertebrate auditory organ. Zool. Anz., Bd. 7.

Bodenstein, Emil 1882 Der Seitenkanal von Cottus gobio. Zeit. f. wiss. Zool., Bd. 37.

Bunker, F. S. 1897 On the structure of the sensory organs of the lateral line of Ameiurus nebulosus. Anat. Anz., Bd. 13.

Clapr, C. M. 1898 The lateral line system of Batrachus tau. Jour. Morph., vol. 15.

CoLe, F. J. 1895 On the cranial nerves of Chimaera monstrosa with a discussion of the lateral line system, ete. Trans. Royal Soc. of Edinb., vol. 38 , part 3 . 
Collinge, W. E. 1894 On the sensory canal system of fishes. Q. J. M. S., vol. 36 .

DE Sìde DE LifCRIX, P. 1884 Recherches sur la ligne laterale des poissons osseux.

Ewart, J. C., AND Mitchell, J. C. 1892 Iateral sense organs of elasmobranchs (Læmargus and skate). Tr. Roy. Soc., Edin.

Fritsch, G. 1884 Ueber Bau und Bedeutung der Kanalsysteme unter der Haut der Selachier. Sitzb. d. Königl. d. Wiss. zu Berlin.

Garman, S. 1888 On the lateral canal system of the Selachia and Holocephala. Bull. Mus. Comp. Zool., vol. 17.

1892 On the lateral canal system of the Selachia and Holocephala. Bull. Mus. Comp. Zool., vol. 17.

Goitel, F. 1891 Recherches sur la ligne latérale de la baudroie (Lophius piscatorius). Arch. Zool. Exp. et Gen., Series 2, vol. 9, pp. 125-190.

Harrison, R. G. 1903 Experimentelle Untersuchungen über die Entwicklung der Sinnesorgane der Seitenlinie bei den Amphibien. Arch. f. mikr. Anat., Bd. 63.

HeILIG, KaRL 1912 Zur Kenntnis der Seitenorgane von Fischen und Amphibien. Areh. für Anat. und Physiol.

Herrick, C. J. 1903 On the morphological and physiological classification of the cutaneous sense organs of fishes. Amer. Nat., vol. 37.

Hofrmann, C. K. 1896 Beiträge zur Entwicklungsgeschichte der Selachií. Morph. Jahrb., Bd. 24.

Houssay, F. 1891 Analysis and critique of P. Mitrophanow's paper on the metametric significance of the organs of the Iateral line of veterbrates. Arch. de Zool. Exp. et Gen., Series 2, vol. 9.

JACOBSON, L. 1813 Extrait d'un memoire sur un organe particulier des sens dans les raies et les squales. Nuov. Bull. d. Sci., Soc. Philomatique de Paris, vol. 6, p. 332.

Kingsbury, B. F. 1895 The lateral line system of sense organs in some American Amphibia, and comparison with the dipnoans. Trans. Am. Mic. Soc., vol. 17.

KLINKHARDT, W. 1905 Entwickelungsgeschichte der Kopfganglien und Sinneslinien der Selachier. Jen. Zeitschr.

I,ANDACRE AND Conger 1913 Origin of the lateral line primordia in Lepidosteus osseus. Jour. Comp. Neur., vol. 23.

Langerhans, P. 1873 Ueber die Haut der Larva von Salamandra maculosa. Arch. f. Mikr. Anat., vol. 9.

Lorenzini, S. 1678 Osservazioni intorno alle Torpedini. Firenze, 1678, London, 1705, Angl.

Leydig, F. 1850 Ueber die Schleimkanäle der Knochenfische. Archiv f. Anat. u. Physiol.

1868 Ueber Organe eines sechsten Sinnes. Nova Acta Acad. C. L. Nat. Curios, vol. 34.

1895 Integument und Hautsinnesorgane der Knochenfische. Zool. Jahrb., Abt. F. Anat. u. Ontog., Bd. 8.

M'Donnell, R. 1862 On the system of the lateral line in fishes. Trans. Roy. Irish Acad., vol. 24. 
Malbranc, M. 1875 Von der Seitenlinie und ihren Sinnesorganen bei Amphibiien. Zeit. f. wiss. Zool., Bd. 26.

Madrer, F. 1892 Hautsinnesorgane, Feder- und Haaranlagen usw. Morph. Jahrb., vol. 18.

Merkel, F. 1880 Ueber die Endigungen die sensiblen Nerven in der Haut der Wirbelthiere. Rostock.

Mitrophanow, P. 1893 Etude embryogénique sur les Sélaciens Arch. de Zool. Exp. et Gen., Series 3, Tome 1.

MoRnILL, A. D. 1897 Innervation of the auditory epithelium of Mustelus eanis. Jour. Morph., vol. 14.

Mullenix, R. C. 1909 The peripheral terminations of the eighth cranial nerve in vertebrates, especially in fishes. Bull. of the Mus. of Comp. Zool., vol. 53, no. 4.

NonRIs, H. W. 1907 The innervation of the lateral line system of Amphiuma. Proc. of the Iowa Acad. of Sc., vol. 14.

PARKER, G. H. 1905 The function of the lateral line organs in fishes. Bull. of the Bureau of Fisheries, 1904.

1910 Influence of the eyes, ears, and other allied sense organs on the movernents of the dogfish, Mustelus canis (Mitchill). Bull. of the Bureau of Fisheries, vol. 29.

Pfưller, Albert 1914 Beiträge zur Kenntnis der Seitensinnesorgane und Kopfanatomie der Macruriden. Jen. Zeitschr., Bd. 52.

Polland, H. B. 1892 The lateral line system in siluroids. Zool. Jahrb.

Reese, A. M. 1910 The lateral line system of Chimæra colliei. Jour. Exp. Zool., vol. 9.

Reтzivs, G. 1905 Ueber die Endigungsweise des Gohörnerven in den Maculae und Cristae Acustice in Gehörlabyrinth der Wirbeltiere. Biol. Unters., N. F., Bd. 12.

Schulze, F. E. 1861 Ueber die Nervenendigung in den sogenannten Schleimkanälen der Fische und über entsprechende Organe der durch Kiemen athmenden Amphibien. Arch. f. Anat. u. Phys.

1870 Ueber die Sinnesorgane der Seitenlinie bei Fischen und Amphibien. Archiv f. mikr. Anat., Bd. 6.

Solger, B. 1879 Neue Untersuchungen zur Anatomie der Seitenorgane der Fische. Arch. f. mikr. Anat., Bd. 17.

1880 Die Seitenorgane der Selachier. Arch. f. mikr. Anat., Bd. 18. 1882 Bemerkung über die Seitenorganketten der Fische. Zool. Anz., Bd. 5.

Stenonis, N. 1664 De muscalis et glandulis observationum specimen eum duabus epistolis quarum una ad. Guil. Pisonum de anatome Rajae, etc. Halnix, 1664.

1667 Elementorum myologix specimen; accedit Canis carchariæ caput dissectum, et dissectus pisces e canum genere. Flor. 1667; also Amst., 1669.

1910 Opera philosophica, 2 vols., Copenhagen.

Wilson, H. V. 1889 The embryology of the sea bass. Bull. U. S. Fish. Comm., vol. 9.

Wilson AND MAtrocks 1897 The lateral sensory anlage in salmon. Anat. Anz., Bd. 13. 